\title{
Coercivity Determines Magnetic Particle Heating
}

\section{Journal Article}

\section{Author(s):}

Starsich, Fabian H.L.; Eberhard, Christian; Boss, Andreas; Hirt, Ann Marie (D; Pratsinis, Sotiris E.

Publication date:

2018-10-10

Permanent link:

https://doi.org/10.3929/ethz-b-000282025

\section{Rights / license:}

In Copyright - Non-Commercial Use Permitted

\section{Originally published in:}

Advanced Healthcare Materials 7(19), https://doi.org/10.1002/adhm.201800287

\section{Funding acknowledgement:}

163243 - Multifunctional nanoparticles for targeted theranostics (SNF) 
${ }^{1}$ Particle Technology Laboratory, Institute of Process Engineering, Department of Mechanical and Process Engineering,

${ }^{2}$ Institute of Diagnostic and Interventional Radiology, University Hospital Zürich, Rämistrasse 100, CH-8091 Zürich, Switzerland.

*Corresponding author:

Sotiris E. Pratsinis; Tel.: +41 4463231 80; fax: +41 4463215 95; e-mail: sotiris.pratsinis@ptl.mavt.ethz.ch

"This is the peer reviewed version of the following article: Starsich, F. H. L., Eberhardt, C., Boss, A., Hirt, A. M., Pratsinis, S. E., Adv. Healthcare Mater. 2018, 7, 1800287, which has been published in final form at https://doi.org/10.1002/adhm.201800287. This article may be used for non-commercial purposes in accordance with Wiley Terms and Conditions for Use of SelfArchived Versions." 
Abstract:

2 Diseased cell treatment by heating with magnetic nanoparticles is hindered by their required high

3 concentrations. A clear relationship between heating efficiency and magnetic properties of nanoparticles has

$4 \quad$ not been attained experimentally yet due to limited availability of magnetic nanoparticles with varying size

5 and composition. Here we use versatile flame aerosol technology for synthesis of 21 types of ferro-

6 /ferrimagnetic nanocrystals with varying composition, size and morphology for hyperthermia and

7 thermoablation therapy. Heating efficiency, magnetic hysteresis and first order reversal curves of these

8 materials are compared. The maximum heating performance occurs near the transition from

9 superparamagnetic to single domain state, regardless of particle composition. Most importantly, the ratio

10 between saturation magnetization and coercivity can be linked to the heating properties of magnetic

11 nanoparticles. Magnetic interaction is controlled by changes in the architecture of the nanoparticles and

12 closely analyzed by first order reversal curves. Silica-coated non-stoichiometric Gd-Zn ferrite exhibits the most promising therapeutic capability at relatively low particle concentrations, as shown in vitro with cancerous prostate cells.

Keywords: magnetic particle heating, hyperthermia, coercivity, iron oxide 


\section{Introduction}

2 Magnetic nanoparticle heating refers to the temperature increase in ferro-/ferrimagnetic nanostructures

3 (typically iron oxides) and their surrounding medium (e.g. cancer cells) by an oscillating external magnetic

4 field ${ }^{[1]}$ The inherent therapeutic applications are promising as biocompatible nanostructures can be locally activated during treatment to thermally destroy diseased tissue and remain otherwise inactive. Therefore, the therapeutic effect can be externally triggered and precisely controlled. This characteristic makes magnetic nanoparticle heating superior over conventional chemotherapy where the injected drugs not only attack cancerous sites but also healthy organs leading to severe side-effects. ${ }^{[2]}$ This advantage has attracted strong interest and led to successful treatments of several malignant tissues, such as prostate cancer ${ }^{[3]}$ and glioblastoma ${ }^{[4]}$. Recent progress in the field with respect to material optimization and in vitro/in vivo studies has been summarized extensively. ${ }^{[5,6]}$

Despite these promising results, wide-spread clinical application is hindered, predominantly, by the required large doses of magnetic nanostructures currently clinically used $\left(112 \mathrm{mg} \mathrm{mL}^{-1}, 0.1-0.7 \mathrm{~mL} \text { per mL tumor }\right)^{[7]}$ for effective thermal damage at the diseased site. This tremendous concentration of un-physiological material might also bear some to date unknown risks of adverse effects and hence should be drastically lowered. For example, nanoparticles were still detectable in the prostate even 17.5 months after administration. ${ }^{[8]}$ Additionally, the required strong magnetic fields for a sufficient temperature increase leads to undesired heating outside the target region. ${ }^{[9]}$ Reduced particle concentrations might also allow also allow monitoring via magnetic resonance imaging. ${ }^{[6]}$ Furthermore, especially diffuse carcinomas are not suitable for direct nanoparticle injection and therefore pose problems in a clinical routine. Under such circumstances, the magnetic particles would have to be administered intravenously to target the diseased site via blood flow which restricts their applied amounts even more (e.g. $~ 0.7 \%$ of injected nanoparticles reach a cancerous nanostructured magnetic systems with respect to their heating efficiency for minimization of the required nanoparticle dose. magnetic field (Neel- and Brownian-relaxation, and hysteresis). ${ }^{[1]}$ For nanoparticles smaller than the 
superparamagnetic limit (e.g. $25 \mathrm{~nm}$ for $\mathrm{Fe}_{3} \mathrm{O}_{4}$ ), heat dissipates by either magnetic dipoles (Neel-relaxation) or entire nanostructures (Brownian-relaxation) seeking to align with the oscillating magnetic field. Larger nanoparticles (> $80 \mathrm{~nm}$ for $\mathrm{Fe}_{3} \mathrm{O}_{4}$ ) can be multi-domain systems, in which hysteresis effects in the form of shifting domain walls dictate the thermal effects. ${ }^{[1]}$ Intermediately sized systems $\left(\sim 25-80 \mathrm{~nm}\right.$ for $\left.\mathrm{Fe}_{3} \mathrm{O}_{4}\right)$ heat through a combination of all three effects while a clear separation is not possible. It is frequently assumed that hysteresis heating is negligible for biomedical applications as comparably strong applied magnetic fields ${ }^{[12]}$ and therefore large single domain magnetic particles are required. ${ }^{[13]}$ The underlying dominant heating mechanism, however, strongly depends generally on the strength and frequency of the applied magnetic field. ${ }^{[14]}$ Besides particle size, material composition ${ }^{[15]}$ or agglomeration ${ }^{[16]}$, and therefore the applied synthesis method, also strongly influence heating efficiency. For example, iron oxides ${ }^{[17]}$, metal iron $^{[18]}$, iron cobalt ${ }^{[19]}$, cobalt ferrite ${ }^{[20]}$, manganese ferrite ${ }^{[21]}$, mesoporous silica nanoparticles ${ }^{[22]}$ or even bacterial magnetosomes ${ }^{[23]}$ and magnetically complex core/shell systems ${ }^{[24]}$ have been reported as excellent candidates for efficient magnetic particle heating.

The preceding simplified summary shows that theoretical predictions of magnetic particle heating effects are a challenging task. An in-depth understanding of the interplay between mechanisms and effects dictating magnetic particle heating is hindered by a missing wide-range experimental verification of the predominant theoretical concepts. This might be due to limited ranges of nanoparticle sizes, compositions or morphologies available by a single synthesis method.

Specific loss power (SLP) is frequently used ${ }^{[11]}$ to compare the magnetic heating efficiencies of nanoparticles from different studies. However, it was recently shown, that the assumptions of linear dependence on concentration and applied field amplitude are not valid. ${ }^{[25]}$ Furthermore, the initial temperature increase used for calculating SLPs is not clearly defined. This makes a comparison of nanomaterials prepared by different methods not straightforward, as surface properties, size-distribution or morphology can vary distinctively between them.

Flame-spray synthesis might overcome that dilemma as it stands out for its product versatility. ${ }^{[26]}$ For example, 18 different flame-made nanomaterials were compared with respect to their fluorescence efficiency. ${ }^{[27]}$ Additionally, this dry process (no solvent-residues due to high-temperature combustion) is scalable $\left(>1 \mathrm{~kg} \mathrm{~h}^{-1}\right),{ }^{[28]}$ both representing key requirements for a successful product translation into clinical 
application, ${ }^{[29]}$ being frequently overlooked. Moreover, with this technology several magnetic nanoparticles of various sizes and compositions, such as $\mathrm{Co},{ }^{[30]} \mathrm{FeC}^{[31]} \mathrm{Fe}_{\mathrm{x}} \mathrm{O}_{\mathrm{y}},{ }^{[32]}$ or $\mathrm{SiO}_{2}$-coated $\mathrm{Fe}_{2} \mathrm{O}_{3}{ }^{[33]}$ and $\mathrm{Zn}_{0.4} \mathrm{Fe}_{2.6} \mathrm{O}_{4}{ }^{[34]}$ have been prepared.

Basic magnetic properties of such ferro-/ferrimagnetic nanoparticles can be analyzed with hysteresis curves providing their saturation magnetization $\left(\mathrm{M}_{\mathrm{s}}\right)$ and coercivity $\left(\mathrm{B}_{\mathrm{c}}\right)$. The $\mathrm{B}_{\mathrm{c}}$ in particular strongly depends on the size of the ferro-/ferrimagnetic system. ${ }^{[35]}$ It remains close to zero for small superparamagnetic (SP) structures and then increases suddenly in the simple single-domain (SD) regime. The $\mathrm{B}_{\mathrm{c}}$ is therefore an excellent parameter to evaluate the SP-SD transition size for various material compositions and morphologies. More detailed information about the magnetic properties of nanomaterials can be obtained from first order reversal curve (FORC) measurements. ${ }^{[36]}$ They provide information on the $\mathrm{B}_{\mathrm{c}}$ distribution, revealing deeper insight into morphology as well as crystal structure ${ }^{[37]}$, instead of (merely) averaged coercivity as given by hysteresis curves,

This study aims to systematically elucidate, for the first time to our knowledge, the correlation of magnetic and material properties with magnetic particle heating efficiencies experimentally, for a wide-range of material compositions and sizes in defined experimental conditions. To this end, 21 magnetic nanoparticles of various sizes, compositions and morphologies were prepared by aerosol technology. Their magnetic properties were closely analyzed and compared to their heating efficiency. For an in-depth understanding, FORCs of representative systems were investigated providing information on the distribution of magnetic properties. Capitalizing on this knowledge, the ferro-/ferrimagnetic nanoparticles were carefully engineered to increase the magnetic particle heating effect. The most promising nanoparticle system, silica-coated $\mathrm{Gd}_{0.225} \mathrm{Zn}_{0.4} \mathrm{Fe}_{2.375} \mathrm{O}_{4}$, was further evaluated with in vitro studies on human PC3 prostate cancer cells.

\section{Experimental}

\section{Particle synthesis}

Various ferro-/ferrimagnetic bare and $\mathrm{SiO}_{2}$-coated iron oxide based nanoparticles (NP), containing $\mathrm{Zn}$ and/or Gd were prepared by flame-spray pyrolysis (FSP). ${ }^{[33]}$ Table S1 summarizes the process conditions for their synthesis. In brief, a liquid precursor solution was fed at 5-8 $\mathrm{mL} \mathrm{min}^{-1}$ through a capillary and was thereafter 
dispersed with 3-5 $\mathrm{L} \mathrm{min}^{-1} \mathrm{O}_{2}$ (all gases PanGas AG, purity > 99\%) into fine droplets. The pressure drop over the capillary was constant at 1.6 bar. The resulting spray was ignited and stabilized by a premixed $\mathrm{CH}_{4} / \mathrm{O}_{2}\left(1.5 / 3.2 \mathrm{~L} \mathrm{~min}^{-1}\right)$ support flame. The spray flame was enclosed by a quartz glass tube (ID = $\left.45 \mathrm{~mm}\right)$ of various lengths (Table S1) and sheathed with $40 \mathrm{~L} \mathrm{~min}^{-1} \mathrm{O}_{2}$. The liquid precursors were prepared by dissolving the required amounts of iron(III) nitrate nonahydrate (Sigma-Aldrich, purity 98\%), zinc-nitrate hexahydrate (Sigma-Aldrich, purity 98\%) and gadolinium(III) nitrate hexahydrate (Sigma-Aldrich, purity $99.99 \%)$ in a 1:1 volume mixture of 2-ethylhexanoic acid (2-EHA, Sigma-Aldrich, 99\%) and ethanol. Prior to production all liquid precursors were magnetically stirred for at least $1 \mathrm{~h}$ at room temperature.

The $\mathrm{SiO}_{2}$-coating was applied by swirl-injection of Hexamethyldisiloxane (HMDSO, Sigma-Aldrich, purity $\geq 99 \%$ ) vapor through a torus ring with 16 equally spaced openings, facing $20^{\circ}$ upstream. ${ }^{[33]}$ The HMDSO vapor was obtained by feeding $\mathrm{N}_{2}$ through a bubbler filled with HMDSO placed in a water bath at $20^{\circ} \mathrm{C}$ and thereafter diluting it with $15 \mathrm{~L} \mathrm{~min}^{-1}$ of additional $\mathrm{N}_{2}$. The nominal $\mathrm{SiO}_{2}$ content in the product was varied by adapting the $\mathrm{N}_{2}$ flow through the bubbler, according to calculations at saturation conditions. Downstream the HMDSO injection, the particle stream was enclosed also by another quartz glass tube $(\mathrm{ID}=45 \mathrm{~mm}$, length $=$ $30 \mathrm{~cm}$ ), which allowed extensive mixing of HMDSO vapor and FSP-made nanoparticles facilitating their $\mathrm{SiO}_{2}$-coating. All nanomaterials were collected further downstream on a glass-fiber filter (Whatman GF6, $257 \mathrm{~mm}$ diameter) with the aid of a vacuum pump (Busch, Seco SV 1040C). No further treatment of the powder was conducted. The quartz tubes were pre-heated for 2 min by combusting particle-free solvent. $\mathrm{SiO}_{2}$-coated (35 wt $\left.\%\right) \mathrm{Gd}_{0.225} \mathrm{Zn}_{0.4} \mathrm{Fe}_{2.375} \mathrm{O}_{4}(7.5 \mathrm{at} \% \mathrm{Gd})$ nanoparticles were surface functionalized with polyethylene glycol (PEG) via melt grafting, as described elsewhere in detail. ${ }^{[38]}$ In brief, $300 \mathrm{mg}$ nanoparticles were grand with $9 \mathrm{~g}$ Poly(ethylene glycol) monomethyl ether (MW $5000 \mathrm{~g} \mathrm{~mol}^{-1}$, SigmaAldrich) in a mortar and transferred to a double-neck round-bottom flask. Then they were flushed for $30 \mathrm{~min}$ under argon atmosphere at room temperature. Thereafter, they were heated to $200{ }^{\circ} \mathrm{C}$ under argon atmosphere for $4 \mathrm{~h}$. After cooling down, the mixture was washed three times with each dichloromethane, ethanol and water via sonication (Branson, $40 \mathrm{kHz}$ ) and centrifugation (7800 rpm). Finally the pellet was dried in air. 
2 Crystal sizes were determined by X-ray diffraction (XRD, Bruker AXS D8 Advanced diffractometer, $\mathrm{Cu} \mathrm{K} \alpha$, $340 \mathrm{kV})$ and fitting of the main diffraction peak $\left(2 \theta \approx 35.6^{\circ}\right)$ via Topas 4 software and the Scherrer equation.

4 Lattice parameters were obtained by Rietvieldt analysis using ICSD 084611 and an internal NiO standard. ${ }^{[39]}$ $5 \quad$ Diffraction patterns were aligned to that standard.

6 The specific surface area (SSA) was measured by a five-point isotherm and the Brunauer-Emmett-Teller method (BET, Micromeritics Tristar II PLUS) at 77K. Prior to measurement, all samples were degassed for 1

$8 \mathrm{~h}$ at $150{ }^{\circ} \mathrm{C}$. Average primary particle diameters, $\mathrm{d}_{\mathrm{BET}}$, were calculated from the SSA, assuming a

9 composition-dependent density and spherical shape. Magnetic hysteresis curves and FORCs were obtained by a vibrating sample magnetometer (VSM, Princeton Measurement Corporation), as described elsewhere. ${ }^{[37]}$

11 Scanning transmission electron microscopy (TEM) images were acquired on a Hitachi HD-2700VD with probe corrector (CEOS) at an acceleration potential of $200 \mathrm{kV}$ (electron gun: cold-field emitter) in the ultrahigh resolution mode. Dynamic light scattering measurements were performed on a Zetasizer (Malvern Instruments) right after sonication for $5 \mathrm{~min}$ (Branson, $40 \mathrm{kHz}$ ).

The performance of all nanoparticles (NP) for magnetic particle heating was evaluated with $2.5 \mathrm{mg}$ of magnetic material in $8 \mu \mathrm{L}$ dimethyl sulfoxide (DMSO). Eppendorf tubes of these colloidal solutions were subjected to an oscillating magnetic field (Magnetherm, NanoTherics Ltd., UK, frequency $=512 \mathrm{kHz}$, intensity $=14.08 \mathrm{kA} \mathrm{m}^{-1}$ ) and the temperature was measured by an infrared camera (Fluke, Ti110). Prior to measurement, each dispersion was sonicated in a bath for $5 \min$ (Branson, $40 \mathrm{kHz}$ ). Magnetic particle heating efficiency was assessed in triplicates (mean $\pm \mathrm{SD}$ ).

\section{In vitro studies}

In vitro biocompatibility was assessed with adherent prostate cancer cells (PC-3, ATCC® CRL-1435, USA) and non-adherent monocytes (THP-1). The PC-3 cells were cultivated in supplemented growth medium $\left(\right.$ Gibco $^{\mathrm{TM}}$ RPMI 1640, Thermo Fisher Scientific) with $10 \%$ fetal bovine serum (Gibco ${ }^{\mathrm{TM}}$, Thermo Fisher Scientific) and $1 \%$ penicillin/streptomycin (PenStrep, Gibco, Thermo Fisher Scientific) at $37^{\circ} \mathrm{C}$ under humidified atmosphere containing 5\% $\mathrm{CO}_{2}$. The PC3 cells were seeded at a density of 10000 cells/well in a flat bottom 96-well plate (100 $\mu \mathrm{L}$ per well) and cultured for $24 \mathrm{~h}$. 
1 For co-incubation of NP with PC-3 cells, sterile nanoparticle suspensions were prepared in unsupplemented RPMI 1640 (Gibco ${ }^{\mathrm{TM}}$ RPMI 1640, Thermo Fisher Scientific) and autoclaved for $20 \mathrm{~min}$ at $121^{\circ} \mathrm{C}$. Desired NP concentrations were adjusted with unsupplemented RPMI 1640 and twofold supplemented growth medium at least 45 min prior co-incubation with PC-3 cells. Growth medium in the flat bottom 96-well plate was replaced with thoroughly vortexed NP suspensions securing sample homogeneity and subsequently incubated for further $24 \mathrm{~h}$. For the PC-3 cells, the 96-well plate containing them was centrifuged at 500g for 5 min at room temperature (RT). The supernatant $(50 \mu \mathrm{L} /$ well) was transferred in a new flat bottom 96 -well plate. The released lactate dehydrogenase activity was determined applying $50 \mu \mathrm{L}$ of CytoTox 96 reagent according to manufacturer instructions (CytoTox 96 Non Radioactive Cytotoxicity Assay, Promega, Madison, WI USA) and incubated in the dark at RT for $15 \mathrm{~min}$. The absorbance was measured at $490 \mathrm{~nm}$ using a plate reader (Epoch 2, BioTek Instruments, VT, USA).

THP-1 cells were cultivated, seeded and incubated with nanoparticles according to previous work. ${ }^{[40]}$ After incubation, the contents of the wells was extracted and centrifuged at $6000 \mathrm{~g}$ for $5 \mathrm{~min}$. The supernatant (50 $\mu \mathrm{L}$ ) was mixed in a new well with $50 \mu \mathrm{L}$ of CytoTox 96 reagent and incubated in the dark at RT for 30 min. Thereafter the absorption was measured at $490 \mathrm{~nm}$ by a plate reader (Mithras2 LB 943).

For in vitro magnetic particle heating, the PC-3 cells were seeded in non-pyrogenic cell culture dishes with a diameter of $35 \mathrm{~mm}$ (35 mm x $10 \mathrm{~mm}$, treated polystyrene, \# 430165, Corning GmbH, Germany) at a density of 200000 cells/dish and cultured in $2 \mathrm{~mL}$ growth medium at $37^{\circ} \mathrm{C}$ under humidified atmosphere containing $5 \% \mathrm{CO}_{2}$. Medium within the dishes was replaced with $1.5 \mathrm{~mL}$ fresh growth medium supplemented with the nanoparticle suspensions at desired concentrations prior to nanoparticle hyperthermia experiments. Samples measured at $490 \mathrm{~nm}$ using a plate reader (Epoch 2, BioTek Instruments, VT, USA). In vitro studies were performed in two separate experiments with quadruplicate measurements (total 8 values, mean $\pm S D$ ). 
1

2

3 A series of 21 different magnetic $\mathrm{Gd}_{\mathrm{x}} \mathrm{Zn}_{0.4} \mathrm{Fe}_{2.6-\mathrm{x}} \mathrm{O}_{4} \mathrm{NP}$ with varying $\mathrm{Gd}$ content, size and $\mathrm{SiO}_{2}$-coating

4 thickness were prepared by $\mathrm{FSP}^{[34]}$ and investigated as agents for magnetic particle heating. The amount of

$5 \mathrm{Zn}$ was chosen to boost their magnetic properties ${ }^{[41]}$ compared to pure iron oxide. Table 1 summarizes their

Table 1: Size and properties of as-prepared flame-made magnetic nanoparticles.

\begin{tabular}{|c|c|c|c|c|c|c|c|}
\hline \multicolumn{3}{|c|}{ Composition } & \multicolumn{5}{|c|}{ Properties } \\
\hline Formula & Gd & $\mathrm{SiO}_{2}$ & dBET & & $\begin{array}{c}\Delta \mathrm{T} \text { after } \\
10 \mathrm{~min}\end{array}$ & & $\mathbf{B}_{\mathbf{C H}}$ \\
\hline & at $\%$ & wt $\%$ & $\mathrm{~nm}$ & $\mathrm{~nm}$ & ${ }^{\circ} \mathrm{C}$ & emu $g^{-1}$ & $\mathrm{mT}$ \\
\hline $\mathrm{Zn}_{0.4} \mathrm{Fe}_{2.6} \mathrm{O}_{4}$ & 0 & & 35.3 & 35.1 & 0.83 & 73.42 & 9.48 \\
\hline $\mathrm{Gd}_{0.075} \mathrm{Zn}_{0.4} \mathrm{Fe}_{2.525} \mathrm{O}_{4}$ & 2.5 & & 36.6 & 33.3 & 3.37 & 67.42 & 8.48 \\
\hline $\mathrm{Gd}_{0.15} \mathrm{Zn}_{0.4} \mathrm{Fe}_{2.45} \mathrm{O}_{4}$ & 5 & & 33.6 & 25.5 & 6.97 & 53.06 & 5.99 \\
\hline $\mathrm{Gd}_{0.225} \mathrm{Zn}_{0.4} \mathrm{Fe}_{2.375} \mathrm{O}_{4}$ & 7.5 & & 34.8 & 26.1 & 15.77 & 38.38 & 3.99 \\
\hline $\mathrm{Gd}_{0.3} \mathrm{Zn}_{0.4} \mathrm{Fe}_{2.3} \mathrm{O}_{4}$ & 10 & & 36.4 & 23.4 & 19.1 & 25.72 & 1.99 \\
\hline $\mathrm{Gd}_{0.9} \mathrm{Zn}_{0.4} \mathrm{Fe}_{1.7} \mathrm{O}_{4}$ & 30 & & 40.6 & 18.3 & -0.17 & 1.37 & 1.48 \\
\hline $\mathrm{Gd}_{0.225} \mathrm{Zn}_{0.4} \mathrm{Fe}_{2.375} \mathrm{O}_{4}$ & 7.5 & & 15.8 & 14.6 & 3.53 & 20.11 & 0.98 \\
\hline $\mathrm{Gd}_{0.225} \mathrm{Zn}_{0.4} \mathrm{Fe}_{2.375} \mathrm{O}_{4}$ & 7.5 & & 21.9 & 22.5 & 29.87 & 35.24 & 0.98 \\
\hline $\mathrm{Gd}_{0.225} \mathrm{Zn}_{0.4} \mathrm{Fe}_{2.375} \mathrm{O}_{4}$ & 7.5 & & 24.4 & 21.4 & 32 & 39.49 & 1.99 \\
\hline $\mathrm{Gd}_{0.225} \mathrm{Zn}_{0.4} \mathrm{Fe}_{2.375} \mathrm{O}_{4}$ & 7.5 & & 28.5 & 22.6 & 24.1 & 35.85 & 2.49 \\
\hline $\mathrm{Fe}_{2} \mathrm{O}_{3}$ & 0 & & 25 & 23 & 1.17 & 39.98 & 15.04 \\
\hline $\mathrm{Zn}_{0.4} \mathrm{Fe}_{2.6} \mathrm{O}_{4}$ & 0 & & 25.3 & 25.7 & 9.47 & 68.38 & 5.99 \\
\hline $\mathrm{Gd}_{0.225} \mathrm{Fe}_{2.775} \mathrm{O}_{4}$ & 7.5 & & 27 & 25.2 & -0.67 & 3.88 & 6.49 \\
\hline $\mathrm{Gd}_{0.15} \mathrm{Zn}_{0.4} \mathrm{Fe}_{2.45} \mathrm{O}_{4}$ & 5 & & 25.1 & 20.3 & 22.87 & 49.27 & 2.98 \\
\hline $\mathrm{Gd}_{0.3} \mathrm{Zn}_{0.4} \mathrm{Fe}_{2.3} \mathrm{O}_{4}$ & 10 & & 27.8 & 21.1 & 25.97 & 28.09 & 0.98 \\
\hline $\mathrm{Gd}_{0.225} \mathrm{Zn}_{0.4} \mathrm{Fe}_{2.375} \mathrm{O}_{4}$ & 7.5 & & 23.7 & 20.4 & 40.9 & 37.3 & 0.98 \\
\hline $\mathrm{Gd}_{0.225} \mathrm{Zn}_{0.4} \mathrm{Fe}_{2.375} \mathrm{O}_{4}$ & 7.5 & 5 & & 23.8 & 13.7 & 45.99 & 2.49 \\
\hline $\mathrm{Gd}_{0.225} \mathrm{Zn}_{0.4} \mathrm{Fe}_{2.375} \mathrm{O}_{4}$ & 7.5 & 15 & & 18.3 & 9.6 & 51.51 & 3.49 \\
\hline $\mathrm{Gd}_{0.225} \mathrm{Zn}_{0.4} \mathrm{Fe}_{2.375} \mathrm{O}_{4}$ & 7.5 & 25 & & 14.3 & 23.5 & 50.64 & 2.98 \\
\hline $\mathrm{Gd}_{0.225} \mathrm{Zn}_{0.4} \mathrm{Fe}_{2.375} \mathrm{O}_{4}$ & 7.5 & 35 & & 18.3 & 42.3 & 53.55 & 2.06 \\
\hline $\mathrm{Gd}_{0.225} \mathrm{Zn}_{0.4} \mathrm{Fe}_{2.375} \mathrm{O}_{4}$ & 7.5 & 50 & & 17.5 & 34 & 44.85 & 2.06 \\
\hline
\end{tabular}

8 Figure 1 shows the XRD patterns of $\mathrm{Gd}_{\mathrm{x}} \mathrm{Zn}_{0.4} \mathrm{Fe}_{2.6-\mathrm{x}} \mathrm{O}_{4}$ with varying $\mathrm{Gd}$ content and approximate $\mathrm{d}_{\mathrm{BET}}=35$

$9 \mathrm{~nm}$ representative of all materials produced here (Figures S1-S4 show XRD patterns of remaining particles).

10 The XRD pattern of pure $\mathrm{Zn}_{0.4} \mathrm{Fe}_{2.6} \mathrm{O}_{4}$ is in excellent agreement to prior flame-made $\mathrm{Zn}$-ferrites. ${ }^{[34,42]}$ Peaks

11 corresponding to spinel ferrite (dashed line), which are identical ${ }^{[43]}$ to $\mathrm{Fe}_{3} \mathrm{O}_{4}$, can clearly be observed for up 
to 12.5 at\% Gd. Note that the addition of $\mathrm{Zn}$ and/or Gd to the iron precursor prevents the formation of lesser magnetic $\mathrm{Fe}_{2} \mathrm{O}_{3}$, which is typically obtained from oxygen-rich flames. ${ }^{[32]}$ For Gd contents above 5 at $\%$ there is a peak at approximately $32^{\circ}$ that could not be assigned to a common phase. Also the spinel-ferrite peakshift to lower angles due to a lattice expansion is in agreement with literature. ${ }^{[1]}$ This is verified by the inset depicting the fitted lattice constant as a function of Gd content. The data follows a linear trend indicating the successful incorporation of $\mathrm{Gd}$ atoms into the $\mathrm{ZnFe}$ matrix.${ }^{[4]}$ Excessive $\mathrm{Gd}$ doping (30 at\%) leads to the predominant formation of a non-spinel structure $\left(25-35^{\circ}\right)$ that could not be assigned to a previously reported phase.

\section{FIGURE 1}

Commonly, saturation magnetization, $\mathrm{M}_{\mathrm{s}}$, and coercivity, $\mathrm{B}_{\mathrm{CH}}$, which are easily determined from magnetic hysteresis curves, are used to characterize the NP magnetic properties. Coercivity, however, has been largely overlooked in connection with magnetic particle heating, but will be analyzed closely here. Also, the heating efficiency is defined as the temperature increase from room-temperature $\Delta \mathrm{T}$ of a particle dispersion after 10 min of exposure to an oscillating magnetic field. ${ }^{[34]}$

Figure $2 \mathrm{a}$ shows the heating efficiency (left axis) and coercivity (right axis) of $\mathrm{Gd}_{\mathrm{x}} \mathrm{Zn}_{0.4} \mathrm{Fe}_{2.6-\mathrm{x}} \mathrm{O}_{4}$ with $\mathrm{d}_{\mathrm{BET}} \approx$ 25 (filled symbols) and $35 \mathrm{~nm}$ (open symbols) as a function of Gd content. The heating efficiency increases similarly for both sizes due to Gd-addition into the $\mathrm{ZnFe}$ matrix until reaching a maximum at $7.5 \mathrm{at} \% \mathrm{Gd}$ for $\mathrm{d}_{\mathrm{BET}} \approx 25 \mathrm{~nm}$ and 10 at $\% \mathrm{Gd}$ for of $\mathrm{d}_{\mathrm{BET}} \approx 35 \mathrm{~nm}$. Increased Gd doping drastically reduces the performance. This can be explained by the formation of a different crystal structure with strongly reduced $\mathrm{M}_{\mathrm{s}}$ compared to the non-stoichiometric ferrite phase formed at lower Gd contents (Figure 1a). The coercivity decreases with increasing Gd content for both $\mathrm{d}_{\mathrm{BET}}$. Interestingly, for the investigated larger NP, although $\mathrm{d}_{\mathrm{BET}}$ remains constant at $35 \mathrm{~nm}$, similar to coercivity, also the crystal size continuously decreases with increasing Gd doping content, down to $27 \mathrm{~nm}$ (Figure S5). This suggests that crystal size rather than primary particle size has a major influence on coercivity and thus on heating efficiency. At the same time, $\mathrm{M}_{\mathrm{s}}$ decreases from 73 ( 0 at $\% \mathrm{Gd})$ down to $26 \mathrm{emu} \mathrm{g}^{-1}(10$ at $\% \mathrm{Gd})$, indicating that the benefit of low $\mathrm{B}_{\mathrm{CH}}$ on magnetic heating is stronger than that of high $\mathrm{M}_{\mathrm{s}}$. For the smaller particles $\left(\mathrm{d}_{\mathrm{BET}} \approx 25 \mathrm{~nm}\right)$, both $\mathrm{d}_{\mathrm{BET}}$ and $\mathrm{d}_{\mathrm{XRD}}$ remain roughly constant independent of $\mathrm{Gd}$ content, while $\mathrm{B}_{\mathrm{CH}}$, on the other hand, is decreasing. This suggests that by 
addition of Gd the superparamagnetic limit shifts to larger sizes. Therefore, through the incorporation of Gd together with $\mathrm{Zn}$ into the Fe-oxide matrix the magnetic properties could be optimized with respect to heating efficiency through alterations in the spin structure. ${ }^{[15,45]}$

\section{FIGURE 2}

The primary particle size of NP was tuned by varying precursor concentration and flame conditions (Table

S1). The TEM images (Figure S6) show that the morphology is not affected by primary particle size. The primary particle size distribution is narrow (Figure S7) and good agreement between average primary particle sizes determined from BET and TEM image counting is obtained. Figure $2 \mathrm{~b}$ shows the heating efficiency (left axis) and coercivity (right axis) for the most promising composition, $\mathrm{Gd}_{0.225} \mathrm{Zn}_{0.4} \mathrm{Fe}_{2.375} \mathrm{O}_{4}$ (corresponding to 7.5 at\% Gd content), as a function of average primary particle diameter, $\mathrm{d}_{\text {BET. }}$ The heating efficiency peaks at $d_{\mathrm{BET}}=23.7 \mathrm{~nm}$. A similar trend had been reported for flame-made $\mathrm{Zn}_{0.4} \mathrm{Fe}_{2.6} \mathrm{O}_{4}$ (maximum at $21.4 \mathrm{~nm})^{[34]}$ and other nanoparticles (maximum $<20 \mathrm{~nm}$ ) ${ }^{[46]}$ Until the point of maximum heating efficiency, coercivity remains low (at approximately $1 \mathrm{mT}$ ). This indicates that the NP are in the superparamagnetic regime. For larger sizes, they shift into the single domain state with steadily increasing coercivity and declining heating efficiency. This again emphasizes the necessity of low coercivity for effective particle heating, which suggests that the maximum heating efficiency occurs at the transition size from the superparamagnetic to the single-domain regime. Interestingly, the crystal size (Figure S8) commits concomitantly a transition at the same coercivity limit, as it does not substantially increase for $\mathrm{d}_{\mathrm{BET}}$ larger than $23 \mathrm{~nm}$. This might be due to formation of polycrystalline particles that increases coercivity and likewise reduces heating efficiency.

\section{Variation of morphology through $\mathrm{SiO}_{2}$-coating}

The most promising $\mathrm{Gd}_{0.225} \mathrm{Zn}_{0.4} \mathrm{Fe}_{2.375} \mathrm{O}_{4}\left(7.5 \mathrm{at} \% \mathrm{Gd}\right.$ and $\left.\mathrm{d}_{\mathrm{BET}} \approx 24 \mathrm{~nm}\right) \mathrm{NP}$ with respect to heating efficiency were in situ coated ${ }^{[47]}$ with $\mathrm{SiO}_{2}$. This coating impacts the inter-particle distance between the magnetic crystals within an aggregate. ${ }^{[48]}$ The TEM images (Figure 3) indicate rather uniform core/shell morphology. The $\mathrm{SiO}_{2}$ (bright fringe) evenly coats the core (dark area) and does not alter the particle morphology, consistent with literature ${ }^{[33]}$. Furthermore, increased $\mathrm{SiO}_{2}$-content results in thicker and uniform shells. The applied $\mathrm{SiO}_{2}$-coating also promotes the surface functionalization of the magnetic nanoparticles. ${ }^{[49]}$ 
2 Figure 4a shows their heating efficiency (left axis, per gram of active material) and coercivity (right axis) as 3 a function of their $\mathrm{SiO}_{2}$ mass fraction (wt \%). At low $\mathrm{SiO}_{2}$ contents $\left(5 \mathrm{wt} \% \mathrm{SiO}_{2}\right)$, the heating efficiency is 4 reduced down to $\Delta \mathrm{T}=9.6{ }^{\circ} \mathrm{C}$. Thereafter it increases to $\Delta \mathrm{T}=42.3{ }^{\circ} \mathrm{C}\left(35 \mathrm{wt} \% \mathrm{SiO}_{2}\right)$, which resembles the obtained $\Delta \mathrm{T}$ values of bare particles $\left(\Delta \mathrm{T}=40.9^{\circ} \mathrm{C}\right)$. The heating efficiency is slightly reduced by further addition of $\mathrm{SiO}_{2}(50 \mathrm{wt} \%)$ that alters the magnetic particle-particle interactions. This trend is also indicated by the coercivity which first increases at low $\mathrm{SiO}_{2}$ contents and afterwards decreases again for higher ones.

\section{FIGURE 4}

The above described and commonly applied analysis of magnetic hysteresis curves, however, does not yield direct information on magnetic interactions and only provides average bulk magnetic properties of nanoparticles. First Order Reversal Curves (FORC), on the other hand, give closer insight into this magnetic coupling and the effective magnetic size via the distribution of magnetic properties that strongly influence the heating performance.

Therefore, the dependence of $\mathrm{SiO}_{2}$-coating on magnetic interaction is analyzed in Figures $4 \mathrm{~b}$-d which show FORCs of $\mathrm{SiO}_{2}$-coated $\mathrm{Gd}_{0.225} \mathrm{Zn}_{0.4} \mathrm{Fe}_{2.375} \mathrm{O}_{4}\left(7.5\right.$ at $\% \mathrm{Gd}, \mathrm{d}_{\mathrm{BET}} \approx 24 \mathrm{~nm}$ ) with (a) 0 , (b) 5 and (c) $35 \mathrm{wt} \%$ of $\mathrm{SiO}_{2}$ content. The horizontal $\mathrm{B}_{\mathrm{CF}}$ (coercivity determined from FORC) spread around the FORC-maximum describes the coercivity distribution. A broad vertical $\mathrm{B}_{\mathrm{UF}}$ (interaction force) distribution around the maximum can be related to a strong magnetic coupling. ${ }^{[37]}$ The FORC-maximum of a single domain magnetic nanocrystal converges with decreasing size along the $\mathrm{B}_{\mathrm{CF}}$-axis towards the origin and marks the superparamagnetic limit of approximately $20-25 \mathrm{~nm}$ (for $\left.\mathrm{Fe}_{3} \mathrm{O}_{4}\right)^{[11]}$. For superparamagnetic crystals, the FORC maximum continuously shifts upwards from the plot origin with decreasing crystal size. ${ }^{[0]}$

The FORCs of bare (Figure 4b) and $35 \mathrm{wt} \% \mathrm{SiO}_{2}$-coated $\mathrm{Gd}_{0.225} \mathrm{Zn}_{0.4} \mathrm{Fe}_{2.375} \mathrm{O}_{4}$ (Figure 4d) are comparable. Their maxima are shifted slightly up from the horizontal axis along the vertical axis indicating superparamagnetism. Their distribution spread in all directions is tight suggesting a narrow size distribution. A low $\mathrm{SiO}_{2}$ content (Figure 4c, $5 \mathrm{wt} \%$ ) leads to a similar location of the FORC maximum, however, also to a broadening of the distribution (in both $\mathrm{B}_{\mathrm{CF}}$ and $\mathrm{B}_{\mathrm{UF}}$-direction) compared to the bare sample (Figure $4 \mathrm{~b}$ ). This 
shows increased magnetic interactions by the close contact between magnetic particles. For higher $\mathrm{SiO}_{2}$ contents (c, $35 \mathrm{wt} \%$ ), however, the distributions narrows again similar to the bare sample as that contact is reduced due to thicker silica film acting as a spacing material. ${ }^{[48]}$ This allows the magnetic nanoparticles to act independently from each other. These changes in the magnetic particle-particle interactions also affect the effective magnetic size, in line with Figure $2 \mathrm{~b}$. Reduced magnetic coupling leads to a reduced effective magnetic size and therefore to a lower coercivity leading consequently to increased heating efficiency. This suggests that solely by a change in particle aggregation, while keeping magnetic primary particle and crystal sizes constant, the magnetic properties (i.e. coercivity) could be tuned.

The increased magnetic interaction for low $\mathrm{SiO}_{2}$ contents compared to the bare sample is not intuitive and requires further investigation. While earlier work on in situ $\mathrm{SiO}_{2}$-coated $\mathrm{Fe}_{2} \mathrm{O}_{3}$ showed a continuous decrease of the coercivity and a narrowing of the FORC distribution for increasing $\mathrm{SiO}_{2}$ content, ${ }^{[33,37]}$ an increase in coercivity similar to this work was recently observed for $\mathrm{Zn}_{0.4} \mathrm{Fe}_{2.6} \mathrm{O}_{4}{ }^{[34]}$ and therefore potentially reflects a dopant related effect. The observed changes in FORCs, however, confirm that magnetic interaction can be controlled by carefully adjusting the $\mathrm{SiO}_{2}$-coating thickness.

\section{Heating efficiency and magnetic properties}

Empirical determination of a measurable material property correlating to its magnetic particle heating performance would be an attractive objective as it could provide quick and reliable means to select material composition and characteristics. In practice, better efficiency would allow for lower particle dosages in regard of a successful in vivo thermal therapy.

Figure 5a shows the heating efficiency of all prepared nanoparticles as a function of coercivity, $\mathrm{B}_{\mathrm{CH}}$, with their associated saturation magnetization $\mathrm{M}_{\mathrm{s}}\left(\mathrm{emu} \mathrm{g}^{-1}\right)$. The data follows a clear trend with low coercivities having the highest heating efficiencies for all particles possessing ferro-/ferrimagnetic properties $\left(M_{s}>20\right.$ emu $\mathrm{g}^{-1}$ ). This dependency can be described by the relationship $\Delta \mathrm{T}=40 / \mathrm{B}_{\mathrm{CH}}$ indicated with the dashed line. Nevertheless, some particle compositions that had no coercivity were paramagnetic and have poor heating efficiency. The variation in heating efficiency for nanoparticles with similar coercivity might be attributed to their $\mathrm{M}_{\mathrm{s}}$ (Figure 5a). Although a higher heating efficiency is loosely related to lower $\mathrm{M}_{\mathrm{s}}$, for comparable $\mathrm{B}_{\mathrm{CH}}$, a high $M_{s}$ results in better heating efficiency. This is best illustrated by the linear dependency between $M_{s}$ 
normalized by $\mathrm{B}_{\mathrm{CH}}$ and efficiency (Figure 5b), which is shown here for the first time to the best of our knowledge. Most interestingly, this novel relationship between these material characteristics applies over varying material compositions, morphologies as well as different size regimes which influence the various heating mechanisms. ${ }^{[51]}$

\section{FIGURE 5}

The frequently studied Rosensweig model ${ }^{[52]}$ does not report a direct dependence on coercivity, although suggesting an increase in heating effect for high $\mathbf{M}_{\mathrm{s}}$. Dutz and Hergt et al.$^{[14,51,53,54]}$ disputed the assumption made in that model and indicate improved magnetic heating for large coercivities. Their experimental verification, however, is restricted to heating effects inferred from hysteresis data. Here, it is shown that maximum heating occurs for nanoparticles at the transition from superparamagnetic to single domain regime (Figure 2b). This transition state, fulfills the condition that the applied field frequency equals the inverse of the relaxation of the magnetic nanoparticles $(\omega \tau=1) \cdot{ }^{[52]}$ It should be noted that initial susceptibility, the ability for a material to be magnetized, is also highest at the transition from superparamagnetic to single domain. This transition boundary with respect to size depends on composition, as materials with similar particle sizes and varying Gd contents (Figure 2a) show distinct differences in coercivity. Through the addition of Gd into the $\mathrm{ZnFe}$ matrix (and also through the addition of $\mathrm{Zn}$ into the Fe matrix) the transition size can be altered, allowing for larger $\mathrm{M}_{\mathrm{s}}$ at the same $\mathrm{B}_{\mathrm{CH}}$ and therefore increased heating efficiency. The transition size theoretically depends on the applied field frequency. ${ }^{[55]}$ Here, coercivity was determined at $10 \mathrm{~Hz}$ whereas heating measurements were conducted at $512 \mathrm{kHz}$. Despite this difference, both $\mathrm{M}_{\mathrm{s}} / \mathrm{B}_{\mathrm{CH}}$ ratio and heating efficiency follow the same trend. This suggests that the frequency dependency is only of minor concern, especially in in light of expected measurement uncertainties regarding heating efficiency and material properties. This is in line with similar heating efficiency trends despite differences in applied frequencies. ${ }^{[46]}$

\section{Biomedical application}

The $\mathrm{Gd}_{0.225} \mathrm{Zn}_{0.4} \mathrm{Fe}_{2.375} \mathrm{O}_{4}(7.5 \mathrm{at} \% \mathrm{Gd})$ with $35 \mathrm{wt} \% \mathrm{SiO}_{2}$ was the most promising composition here, due to its highest heating efficiency. Note that the incorporation of Gd alone, omitting Zn doping, into the iron oxide matrix $\left(\mathrm{Gd}_{0.225} \mathrm{Fe}_{2.775} \mathrm{O}_{4}\right)$ makes it inapplicable for any thermal treatment by eliminating all superparamagnetic properties. At lower contents $\left(\mathrm{Gd}_{0.02} \mathrm{Fe}_{2.98} \mathrm{O}_{4}\right)$, however, $\mathrm{Gd}$ was shown to increase 
heating efficiency. ${ }^{[56]}$ Here, only the presence of both Gd and $\mathrm{Zn}$ results in the strong increase in magnetic heating efficiency due to reduced coercivity (Figures $2 b, 4 c$ ). Sotiriou et al. ${ }^{[57]}$ reported an ILP value of 0.74 $\mathrm{nH} \mathrm{m} \mathrm{kg}^{-1}$ for flame-made $\mathrm{Fe}_{2} \mathrm{O}_{3}$ of similar properties to those here (Figure 5a). The currently best performing sample $\left(\mathrm{SiO}_{2}\right.$-coated $\left.\mathrm{Gd}_{0.225} \mathrm{Zn}_{0.4} \mathrm{Fe}_{2.375} \mathrm{O}_{4}\right)$ outperforms this material by a factor of 25 . Therefore it is a serious competition even to the best performing commercial and in literature reported systems, with values between 0.15 and $3.1 \mathrm{nH} \mathrm{m}^{2} \mathrm{~kg}^{-1} \cdot{ }^{[58]}$

\section{FIGURE 6}

Finally, the biocompatibility of $\mathrm{SiO}_{2}$-coated $\mathrm{Gd}_{0.225} \mathrm{Zn}_{0.4} \mathrm{Fe}_{2.375} \mathrm{O}_{4}$ for thermal therapy was analyzed in vitro.

To this end, the system was firstly investigated with respect to its cytotoxicity (Figure S9). Biocompatibility up to $500 \mathrm{mg} \mathrm{L}^{-1}$ with cancerous prostate PC3 cells and equally low cytotoxicity to leukemic THP1 cells as commercially available $\mathrm{SiO}_{2}$ (Aerosil 200, from MSDS: $\mathrm{LD}_{50}>3160 \mathrm{mg} \mathrm{kg}^{-1}$ ) is shown. Thereafter, the particles were added to PC 3 cells at various concentrations and magnetically heated for $15 \mathrm{~min}$, as well as not heated as a control. Figure 6 shows the resulting cell death measured via Lactate dehydrogenase (LDH) assay relative to full lysis. Cells with magnetic nanoparticles but no thermal treatment showed no toxicity. For the lowest investigated concentration $\left(8.3 \mathrm{mg} \mathrm{mL}^{-1}\right)$, no clear treatment effect could be observed. For higher nanoparticle doses (> $\left.16.7 \mathrm{mg} \mathrm{mL}^{-1}\right)$, however, a clear therapeutic effect of the magnetic heating can be observed that increases for rising concentrations. Most importantly, the applied concentrations $(<33 \mathrm{mg}$ $\mathrm{mL}^{-1}$ ) are all substantially lower than clinically used ${ }^{[7]}$ dispersions of $112 \mathrm{mg} \mathrm{mL}^{-1}$. Furthermore, $\mathrm{SiO}_{2}$-coated (35 wt $\%$ ) $\mathrm{Gd}_{0.225} \mathrm{Zn}_{0.4} \mathrm{Fe}_{2.375} \mathrm{O}_{4}(7.5 \mathrm{at} \% \mathrm{Gd}$ ) nanoparticles were surface-functionalized with polyethylene glycol via scalable melt grafting. ${ }^{[38]}$ A stable hydrodynamic diameter of the PEGylated particles of approximately $200 \mathrm{~nm}$ was measured for one hour, as shown in Figure S10.

\section{Conclusions}

The efficiency of 21 different flame-made ferro-/ferrimagnetic Gd-Zn-ferrite nanoparticles for magnetic particle heating was compared. Particle morphology, size, composition and magnetic properties were analyzed closely and contrasted to their heating efficiencies ( $\Delta \mathrm{T}$ after $10 \mathrm{~min}$ ). This revealed that the best performance of a ferro-/ferrimagnetic system is at its transition from superparamagnetic to single domain 
state, at which the ratio of saturation magnetization to coercivity is maximized. As such it can serve as a general criterion to optimize heating efficiency, independent of structural properties. This superparamagnetic limit, however, is composition-dependent and could be adjusted by Zn-and Gd doping. Furthermore, by $\mathrm{SiO}_{2}$-coating, the magnetic coupling of the ferrite cores could controlled precisely, as analyzed in detail by first order reversal curves (FORCs). The $\mathrm{Gd}_{0.225} \mathrm{Zn}_{0.4} \mathrm{Fe}_{2.375} \mathrm{O}_{4}$ with $35 \mathrm{wt} \% \mathrm{SiO}_{2}$ coating was identified as the most promising composition for magnetic particle thermal therapy at much lower concentration than clinically applied amounts, as shown in vitro with cancerous prostate PC3 cells. However, more detailed investigations under biological relevant conditions, such as inverted cell configurations ${ }^{[59]}$ or in vivo studies, are required. The so far shown therapeutic efficiency and its dependence on particle coercivity along with the employed scalable synthesis method and product biocompatibility renders the developed nanoparticles here most promising for a fast translation to small-animal or even clinical studies.

\section{Acknowledgments:}

We thank Dr. Inge Herrmann (Empa, Switzerland) for assistance with the cytotoxicity studies. This research was funded by the Swiss National Science Foundation (Grant: 205320_163243).

\section{References:}

[1] R. K. Gilchrist, R. Medal, W. D. Shorey, R. C. Hanselman, J. C. Parrott, C. B. Taylor, Ann. Surg. 1957, 146, 596.

[2] C. L. Shapiro, A. Recht, N. Engl. J. Med. 2001, 344, 1997.

[3] M. Johannsen, U. Gneveckow, B. Thiesen, K. Taymoorian, C. H. Cho, N. Waldöfner, R. Scholz, A. Jordan, S. A. Loening, P. Wust, Eur. Urol. 2007, 52, 1653.

[4] K. Maier-Hauff, F. Ulrich, D. Nestler, H. Niehoff, P. Wust, B. Thiesen, H. Orawa, V. Budach, A. Jordan, J. Neurooncol. 2011, 103, 317.

[5] C. Blanco-Andujar, F. J. Teran, D. Ortega, Iron Oxide Nanoparticles Biomed, Elsevier, 2018. 
$1 \quad$ [6] K. Mahmoudi, A. Bouras, D. Bozec, R. Ivkov, C. Hadjipanayis, Int. J. Hyperth. 2018.

2 [7] B. Thiesen, A. Jordan, Int. J. Hyperth. 2008, 24, 467.

3 [8] M. Johannsen, U. Gneveckow, K. Taymoorian, B. Thiesen, N. Waldöfner, R. Scholz, K. Jung, A. Jordan, P. Wust, S. A. Loening, Int. J. Hyperth. 2007, 23, 315.

5 [9] M. Johannsen, B. Thiesen, P. Wust, A. Jordan, Int. J. Hyperth. 2010, 26, 790.

6 [10] S. Wilhelm, A. J. Tavares, Q. Dai, S. Ohta, J. Audet, H. F. Dvorak, W. C. W. Chan, Nat. Rev. Mater 2016, 1,1 .

[11] A. G. Kolhatkar, A. C. Jamison, D. Litvinov, R. C. Willson, T. R. Lee, Int. J. Mol. Sci. 2013, 14, 15977.

[12] H. Mamiya, J. Nanomater. 2013, 2013, 1.

[13] F. Gazeau, M. Lévy, C. Wilhelm, Nanomedicine 2008, 3, 831.

[14] R. Hergt, S. Dutz, M. Zeisberger, Nanotechnology 2010, 21, 15706.

[15] J. Jang, H. Nah, J.-H. Lee, S. Moon, M. Kim, J. Cheon, Angew. Chemie Int. Ed. 2009, 48, 1234.

[16] D. F. Coral, P. Mendoza Zélis, M. Marciello, M. D. P. Morales, A. Craievich, F. H. Sánchez, M. B. Fernández van Raap, Langmuir 2016, 32, 1201.

[17] P. Guardia, R. Di Corato, L. Lartigue, C. Wilhelm, A. Espinosa, M. Garcia-Hernandez, F. Gazeau, L. Manna, T. Pellegrino, ACS Nano 2012, 6, 3080.

[18] B. Mehdaoui, A. Meffre, L.-M. Lacroix, J. Carrey, S. Lachaize, M. Respaud, M. Gougeon, B. Chaudret, J. Appl. Phys. 2010, 107, 09A324.

[19] J. Alonso, H. Khurshid, V. Sankar, Z. Nemati, M. H. Phan, E. Garayo, J. A. García, H. Srikanth, J. Appl. Phys. 2015, 117, 17.

[20] A. Sathya, P. Guardia, R. Brescia, N. Silvestri, G. Pugliese, S. Nitti, L. Manna, T. Pellegrino, Chem. Mater. 2016, 28, 1769. 
[22] C. Tao, Y. Zhu, Dalt. Trans. 2014, 43, 15482.

[23] E. Alphandéry, S. Faure, O. Seksek, F. Guyot, I. Chebbi, ACS Nano 2011, 5, 6279.

[24] J. H. Lee, J. T. Jang, J. S. Choi, S. H. Moon, S. H. Noh, J. W. Kim, J. G. Kim, I. S. Kim, K. I. Park, J. Cheon, Nat. Nanotechnol. 2011, 6, 418.

[25] I. Conde-Leboran, D. Baldomir, C. Martinez-Boubeta, O. Chubykalo-Fesenko, M. Del Puerto Morales, G. Salas, D. Cabrera, J. Camarero, F. J. Teran, D. Serantes, J. Phys. Chem. C 2015, 119, 15698.

[26] R. Strobel, S. E. Pratsinis, J. Mater. Chem. 2007, 17, 4743.

[27] F. H. L. Starsich, P. Gschwend, A. Sergeyev, R. Grange, S. E. Pratsinis, Chem. Mater. 2017, 29, 8158.

[28] R. Mueller, L. Madler, S. E. Pratsinis, Chem. Eng. Sci. 2003, 58, 1969.

[29] N. Desai, AAPS J. 2012, 14, 282.

[30] R. N. Grass, W. J. Stark, J. Mater. Chem. 2006, 16, 1825.

[31] I. K. Herrmann, R. N. Grass, D. Mazunin, W. J. Stark, Chem. Mater. 2009, 21, 3275.

[32] R. Strobel, S. E. Pratsinis, Adv. Powder Technol. 2009, 20, 190.

[33] A. Teleki, M. Suter, P. R. Kidambi, O. Ergeneman, F. Krumeich, B. J. Nelson, S. E. Pratsinis, Chem. Mater. 2009, 21, 2094.

[34] F. H. L. Starsich, G. A. Sotiriou, M. C. Wurnig, C. Eberhardt, A. M. Hirt, A. Boss, S. E. Pratsinis, Adv. Healthc. Mater. 2016, 5, 2698.

[35] U. Jeong, X. Teng, Y. Wang, H. Yang, Y. Xia, in Adv. Mater., 2007, 19, 33.

[36] M. Kumari, M. Widdrat, É. Tompa, R. Uebe, D. Schüler, M. Pósfai, D. Faivre, A. M. Hirt, J. Appl. Phys. 2014, 116, 124304.

[37] A. M. Hirt, G. A. Sotiriou, P. R. Kidambi, A. Teleki, J. Appl. Phys. 2014, 115, 44314.

[38] K. Keevend, G. Panzarasa, F. H. L. Starsich, M. Zeltner, A. Spyrogianni, E. Tsolaki, G. Fortunato, S. 
E. Pratsinis, S. Bertazzo, I. K. Herrmann, Chem. Commun. 2018, 54, 2914.

[39] B. Ohtani, O. O. Prieto-Mahaney, D. Li, R. Abe, J. Photochem. Photobiol. A Chem. 2010, 216, 179.

[40] M. T. Matter, F. Starsich, M. Galli, M. Hilber, A. A. Schlegel, S. Bertazzo, S. E. Pratsinis, I. K. Herrmann, Nanoscale 2017, 9, 8418.

[41] Y. Yang, X. L. Liu, Y. Yang, W. Xiao, Z. W. Li, D. S. Xue, F. S. Li, J. Ding, J. Mater. Chem. C 2013, $1,2875$.

[42] F. M. Hilty, A. Teleki, F. Krumeich, R. Buchel, R. F. Hurrell, S. E. Pratsinis, M. B. Zimmermann, Nanotechnology 2009, 20, 475101.

[43] S. H. Sun, H. Zeng, D. B. Robinson, S. Raoux, P. M. Rice, S. X. Wang, G. X. Li, J. Am. Chem. Soc. 2004, 126, 273.

[44] N. K. Prasad, K. Rathinasamy, D. Panda, D. Bahadur, J. Mater. Chem. 2007, 17, 5042.

[45] J. H. Lee, Y. M. Huh, Y. Jun, J. Seo, J. Jang, H. T. Song, S. Kim, E. J. Cho, H. G. Yoon, J. S. Suh, et al., Nat. Med. 2007, 13, 95 .

[46] A. E. Deatsch, B. A. Evans, J. Magn. Magn. Mater. 2014, 354, 163.

[47] A. Teleki, M. C. Heine, F. Krumeich, M. K. Akhtar, S. E. Pratsinis, Langmuir 2008, 24, 12553.

[48] G. A. Sotiriou, F. Starsich, A. Dasargyri, M. C. Wurnig, F. Krumeich, A. Boss, J. C. Leroux, S. E. Pratsinis, Adv. Funct. Mater. 2014, 24, 2818.

[49] F. Q. Tang, L. L. Li, D. Chen, Adv. Mater. 2012, 24, 1504.

[50] C. R. Pike, A. P. Roberts, K. L. Verosub, Geophys. J. Int. 2001, 145, 721.

[51] S. Dutz, R. Hergt, Nanotechnology 2014, 25, 452001.

[52] R. E. Rosensweig, J. Magn. Magn. Mater. 2002, 252, 370.

[53] S. Dutz, R. Hergt, J. Mürbe, R. Müller, M. Zeisberger, W. Andrä, J. Töpfer, M. E. Bellemann, J. Magn. Magn. Mater. 2007, 308, 305.

[54] R. Hergt, S. Dutz, M. Röder, J. Phys. Condens. Matter 2008, 20, 385214. 
[55] F. Hrouda, Geophys. J. Int. 2011, 187, 1259. 5 8

[56] P. Drake, H.-J. Cho, P.-S. Shih, C.-H. Kao, K.-F. Lee, C.-H. Kuo, X.-Z. Lin, Y.-J. Lin, J. Mater. Chem. 2007, 17, 4914.

[57] G. A. Sotiriou, M. A. Visbal-Onufrak, A. Teleki, E. J. Juan, A. M. Hirt, S. E. Pratsinis, C. Rinaldi, Chem. Mater. 2013, 25, 4603.

[58] M. Kallumadil, M. Tada, T. Nakagawa, M. Abe, P. Southern, Q. A. Pankhurst, J. Magn. Magn. Mater. 2009, 321, 1509.

[59] A. Spyrogianni, I. K. Herrmann, M. S. Lucas, J. C. Leroux, G. A. Sotiriou, Nanomedicine 2016, 11, 2483.

[60] T. J. Brunner, P. Wick, P. Manser, P. Spohn, R. N. Grass, L. K. Limbach, A. Bruinink, W. J. Stark, Environ. Sci. Technol. 2006, 40, 4374.

(1)

(1)
4 16

\section{7} 9 20 21 2 23 
2 Figure 1: (a) X-ray diffraction patterns of $\mathrm{Gd}_{\mathrm{x}} \mathrm{Zn}_{0.4} \mathrm{Fe}_{2.6-\mathrm{x}} \mathrm{O}_{4}$ with varying $\mathrm{Gd}$ content $(0-30$ at $\%)$ and $\mathrm{d}_{\mathrm{BET}}=$

$3 \quad 35 \mathrm{~nm}$. Inset shows corresponding spinel-ferrite lattice constant as function of Gd content. Dashed line

4 indicates peaks for spinel ferrite, $\mathrm{Fe}_{3} \mathrm{O}_{4}$.

5 Figure 2: Heating efficiency and coercivity (obtained from hysteresis curves) for (a) $\mathrm{Gd}_{\mathrm{x}} \mathrm{Zn}_{0.4} \mathrm{Fe}_{2.6-\mathrm{x}} \mathrm{O}_{4}$ with

$6 \mathrm{~d}_{\mathrm{BET}}$ of 25 (filled symbols) and $35 \mathrm{~nm}$ (open symbols) as a function of Gd content and for (b)

$7 \quad \mathrm{Gd}_{0.225} \mathrm{Zn}_{0.4} \mathrm{Fe}_{2.375} \mathrm{O}_{4}(7.5$ at $\% \mathrm{Gd})$ as a function of $\mathrm{d}_{\mathrm{BET}}$.

8 Figure 3: Transmission electron microscopy images of (a) bare $\mathrm{Gd}_{0.225} \mathrm{Zn}_{0.4} \mathrm{Fe}_{2.375} \mathrm{O}_{4}$ nanoparticles and 9 coated ones with (b) 15 and (c) $35 \mathrm{wt} \% \mathrm{SiO}_{2}$.

Figure 4: (a) Heating efficiency and coercivity (obtained from hysteresis curves) for $\mathrm{SiO}_{2}$-coated

$\mathrm{Gd}_{0.225} \mathrm{Zn}_{0.4} \mathrm{Fe}_{2.375} \mathrm{O}_{4}\left(7.5 \mathrm{at} \% \mathrm{Gd}, \mathrm{d}_{\mathrm{BET}}=24 \mathrm{~nm}\right)$ as a function of $\mathrm{SiO}_{2}$ content. Corresponding first order reversal curves for samples with (a) 0 , (b) 5 and (c) $35 \mathrm{wt} \% \mathrm{SiO}_{2}$ coating.

Figure 5: (a) Heating efficiency as a function of coercivity (obtained from hysteresis curves) for all 21 nanoparticle systems. Saturation magnetization $\mathrm{M}_{\mathrm{S}}$ per gram of magnetic material is shown for each system. (b) Heating efficiency as a function of the ratio of saturation magnetization to coercivity (obtained from hysteresis curves, $\left.\mathrm{M}_{\mathrm{s}} / \mathrm{B}_{\mathrm{CH}}\right)$.

Figure 6: $\mathrm{PC} 3$ cell death relative full lysis (Triton $\mathrm{X}$ ) under magnetic particle heating treatment of $\mathrm{SiO}_{2}$ coated $(35 \mathrm{wt} \%) \mathrm{Gd}_{0.225} \mathrm{Zn}_{0.4} \mathrm{Fe}_{2.375} \mathrm{O}_{4}\left(7.5 \mathrm{at} \% \mathrm{Gd}, \mathrm{d}_{\mathrm{BET}}=24\right)$ at different particle concentrations.

\section{Figures:}




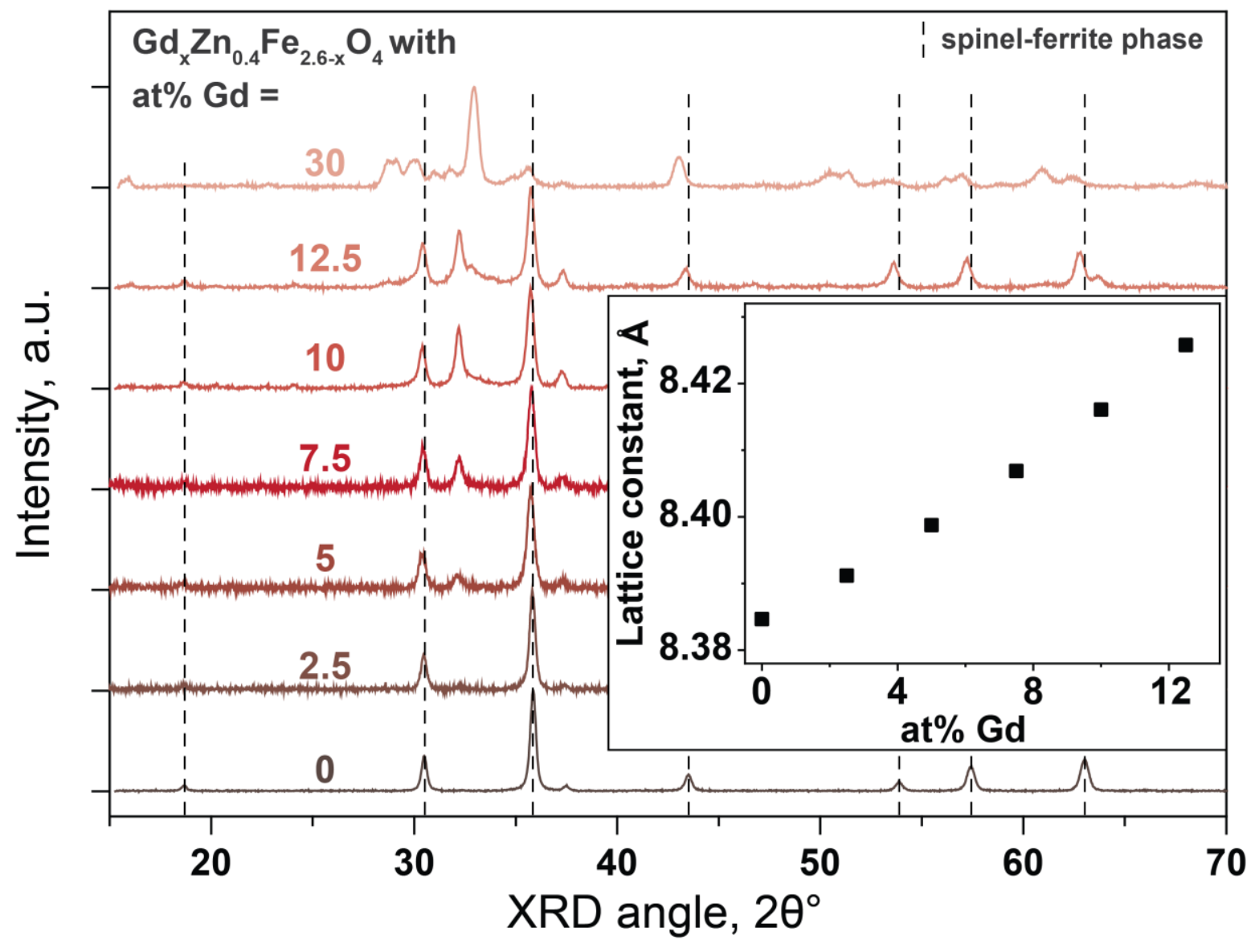

1

2

3

4

5

6

7

8

9

10

Figure 1 

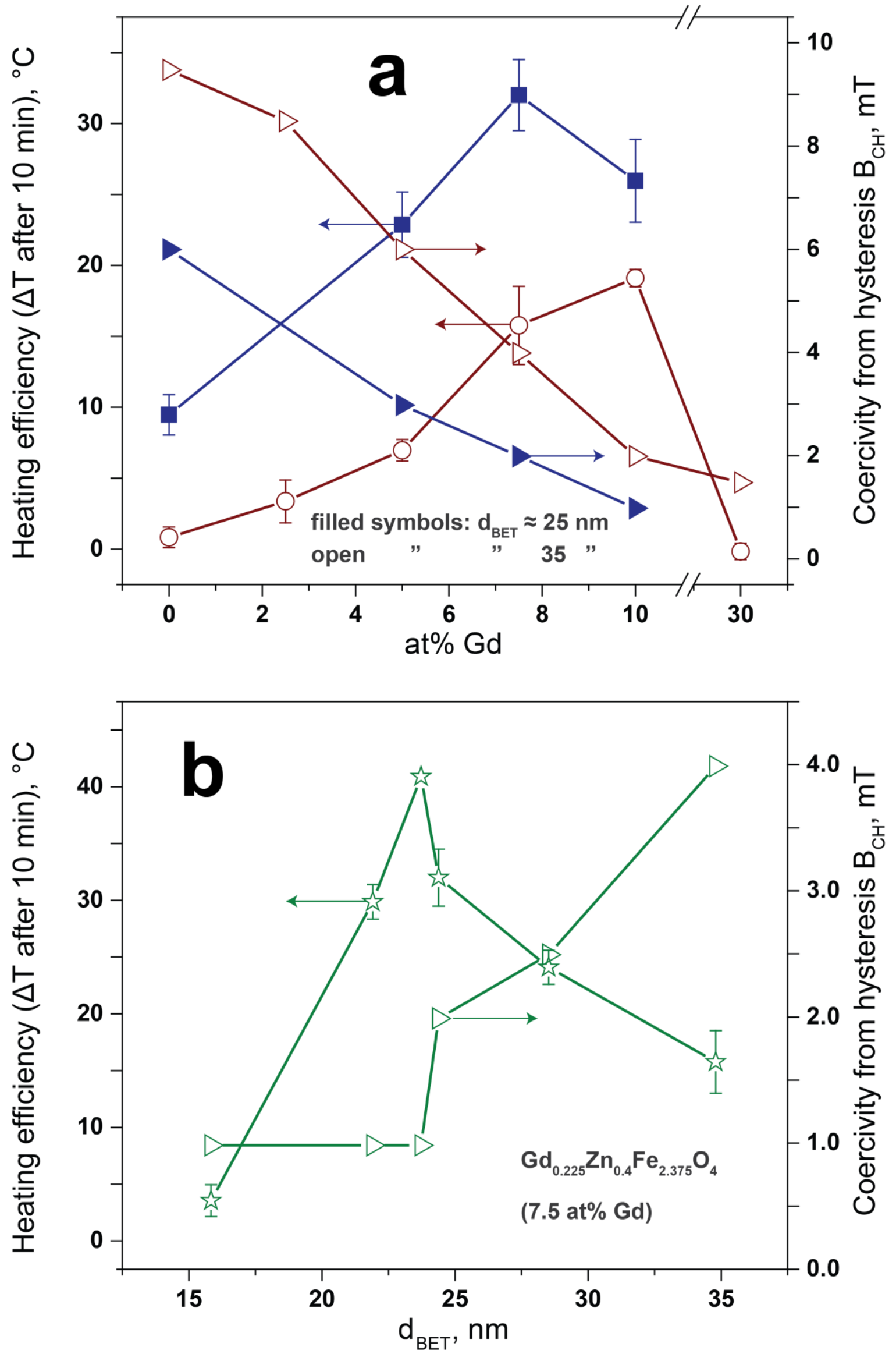

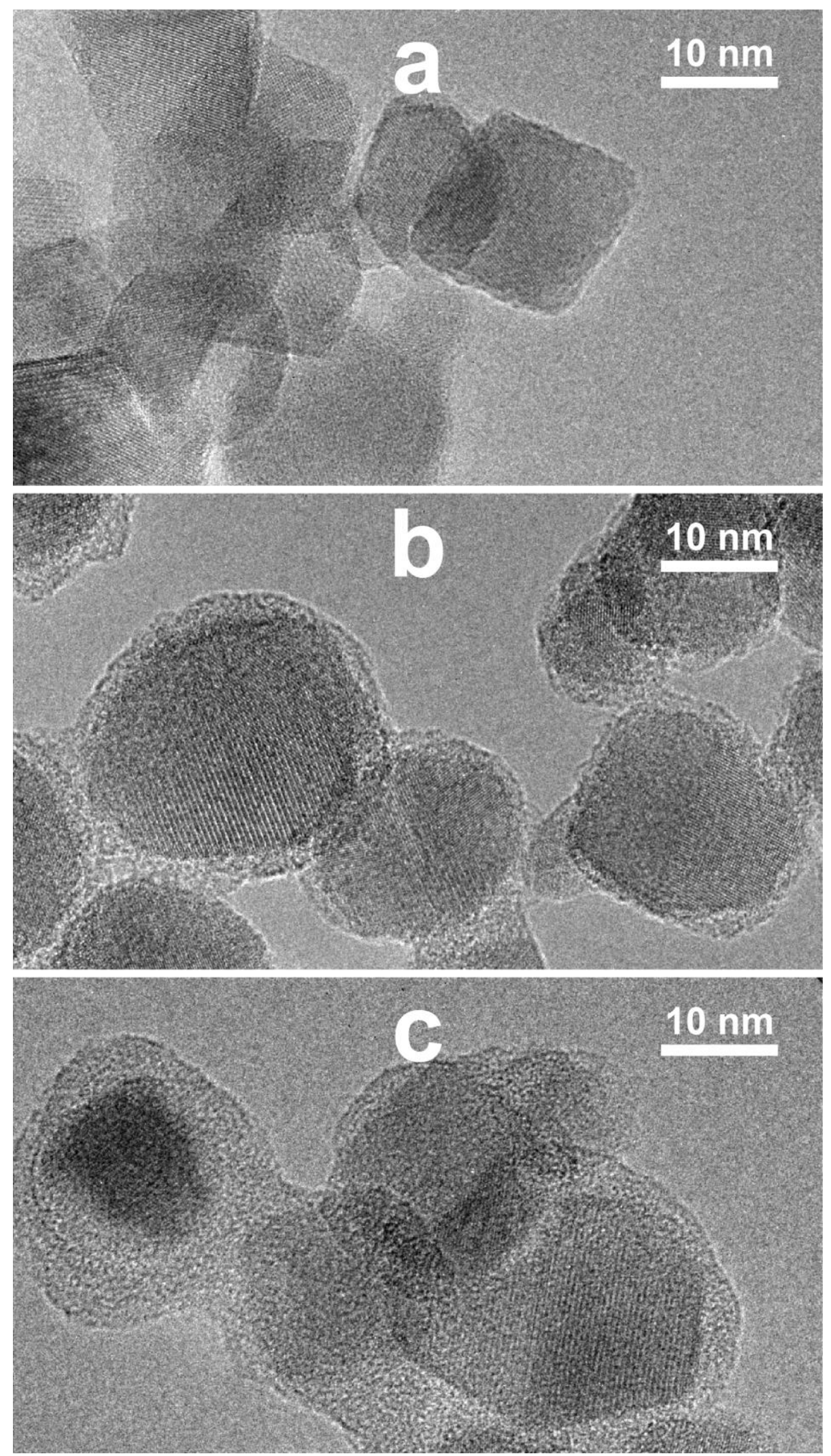

2

3

Figure 3 

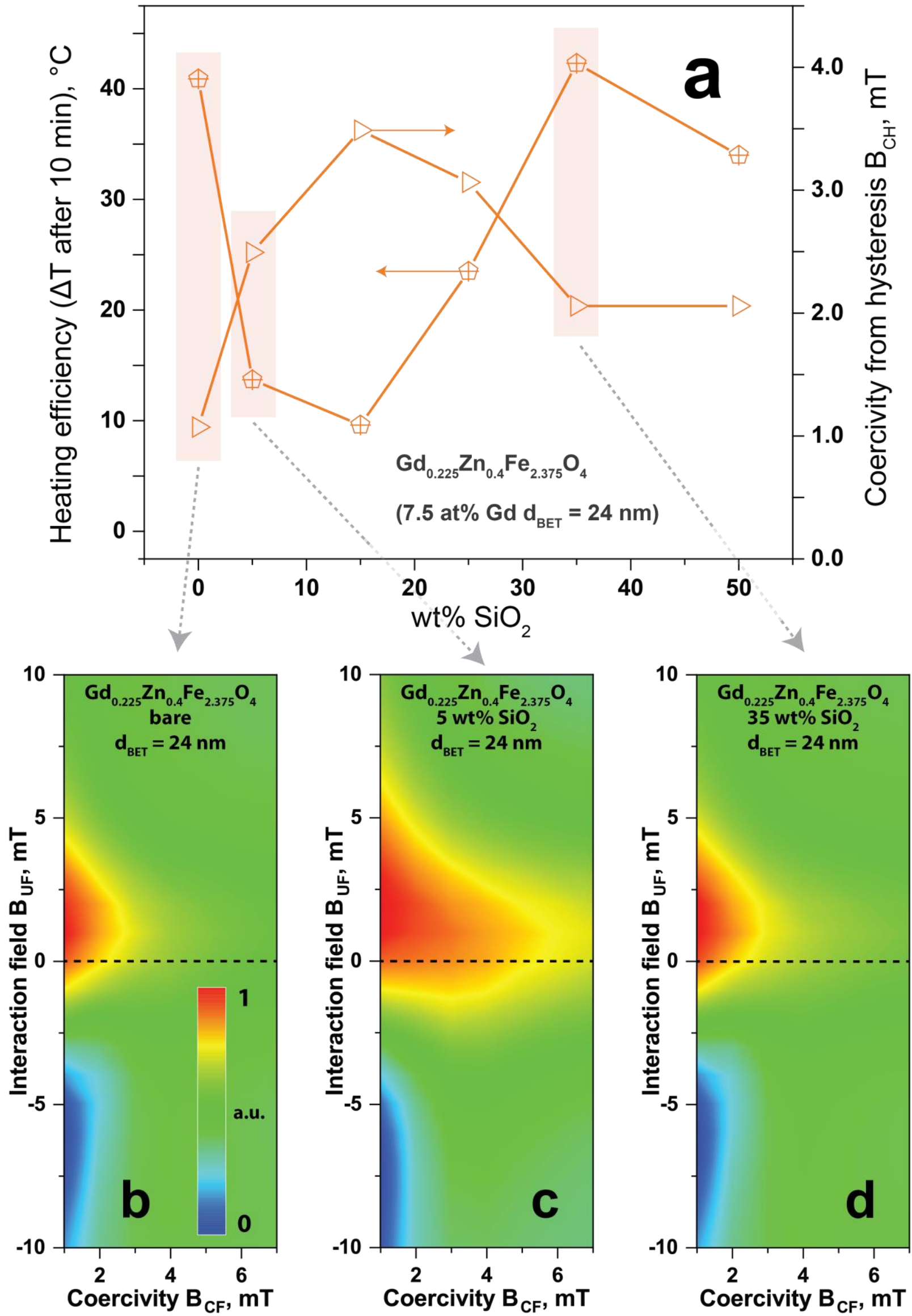

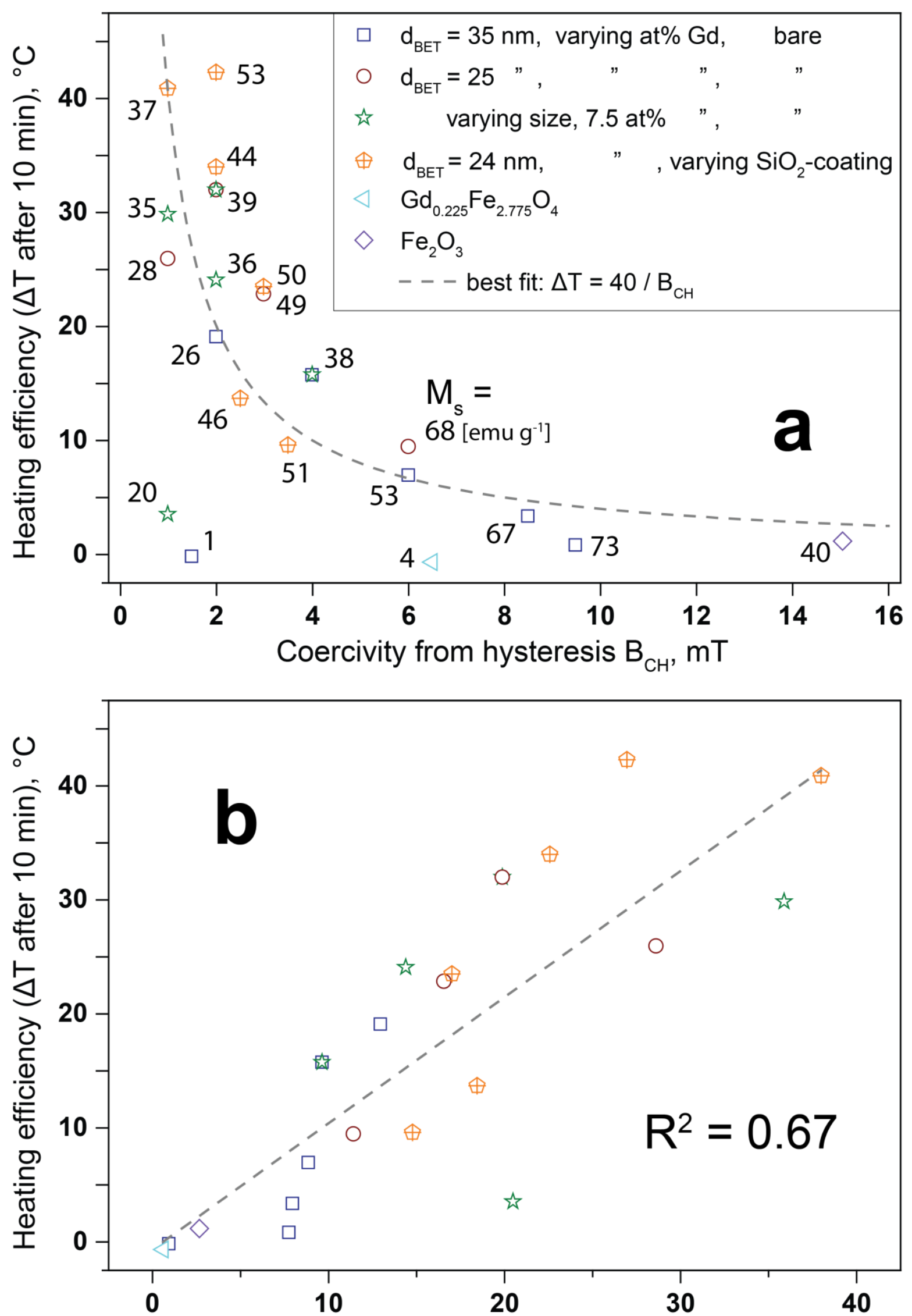

Saturation magnetization $M_{S} /$ coercivity from hysteresis $B_{C H}$ 


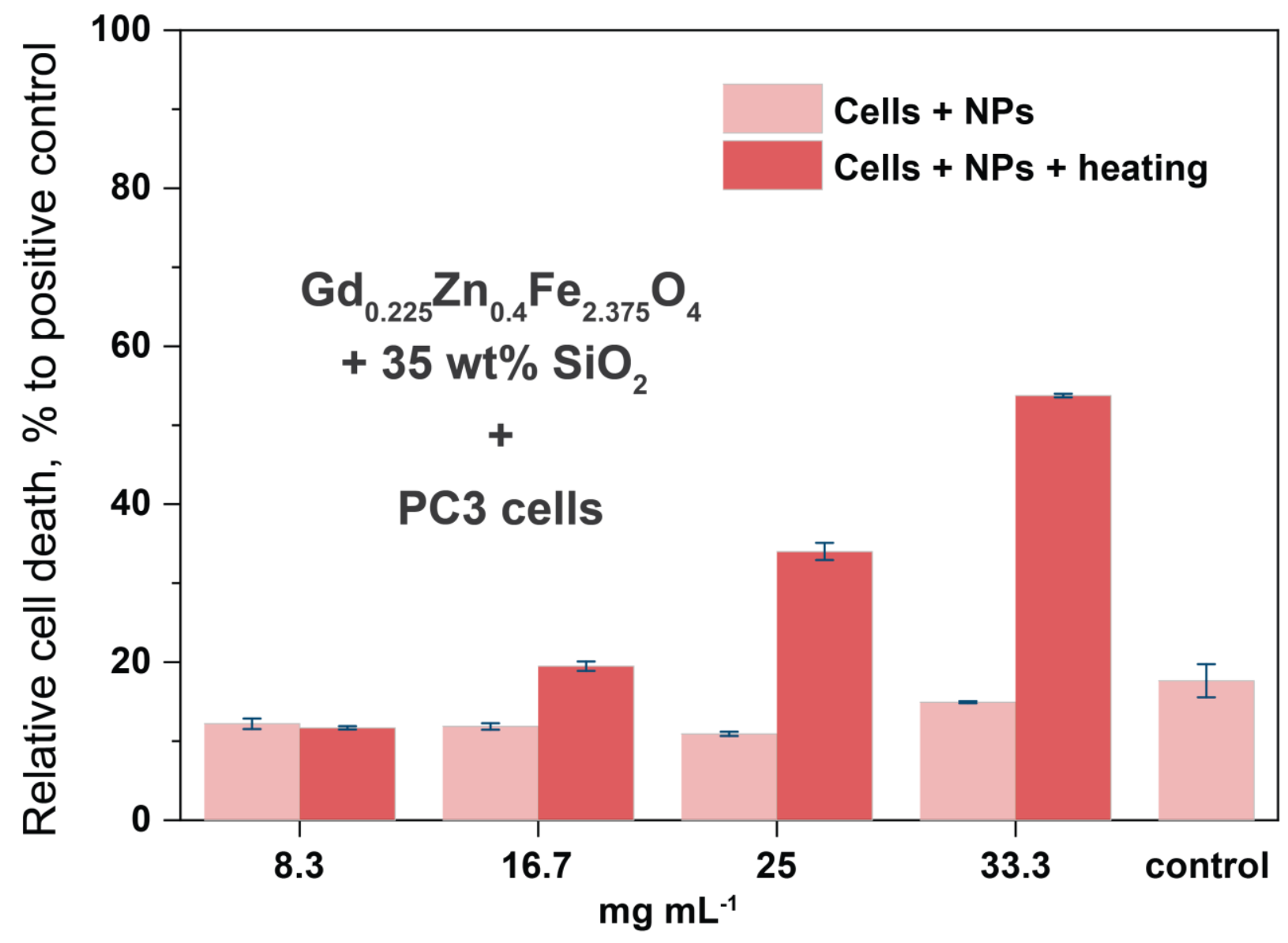




\section{SUPPORTING INFORMATION}

3

\section{Coercivity determines magnetic particle heating}

5

6

Fabian H.L. Starsich ${ }^{1}$, Christian Eberhardt ${ }^{2}$, Andreas Boss ${ }^{2}$, Ann. M. Hirt $^{3}$, Sotiris E. Pratsinis ${ }^{1, *}$

8

9

${ }^{1}$ Particle Technology Laboratory, Institute of Process Engineering, Department of Mechanical and Process

Engineering, ETH Zurich, Sonneggstrasse 3, CH-8092 Zurich, Switzerland

11

${ }^{2}$ Institute of Diagnostic and Interventional Radiology, University Hospital Zürich, Rämistrasse 100,

CH-8091 Zürich, Switzerland.

14

${ }^{3}$ Institute of Geophysics, ETH Zürich, Sonneggstrasse 5, CH-8092 Zürich, Switzerland.

16

*Corresponding author:

Sotiris E. Pratsinis; Tel.: +41 4463231 80; fax: +41 4463215 95; e-mail: sotiris.pratsinis@ptl.mavt.ethz.ch

19

20

06.01 .2021

Submitted to:

Advanced Healthcare Materials 


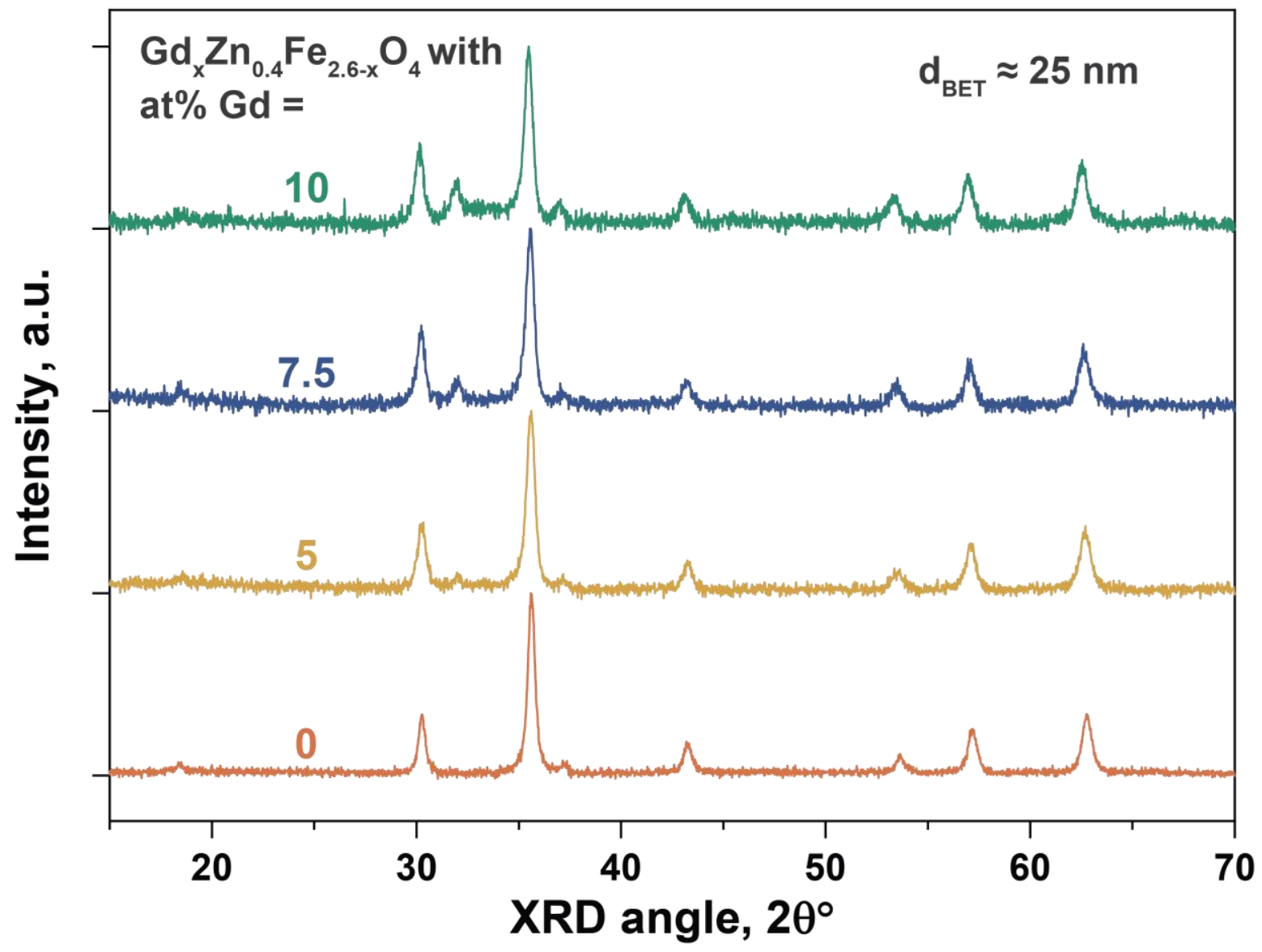

1

Figure S1: X-ray diffraction patterns of $\mathrm{Gd}_{\mathrm{x}} \mathrm{Zn}_{0.4} \mathrm{Fe}_{2.6-\mathrm{x}} \mathrm{O}_{4}$ with varying $\mathrm{Gd}$ content $(0-30$ at $\%)$ and $3 \quad \mathrm{~d}_{\mathrm{BET}}=25 \mathrm{~nm}$. 


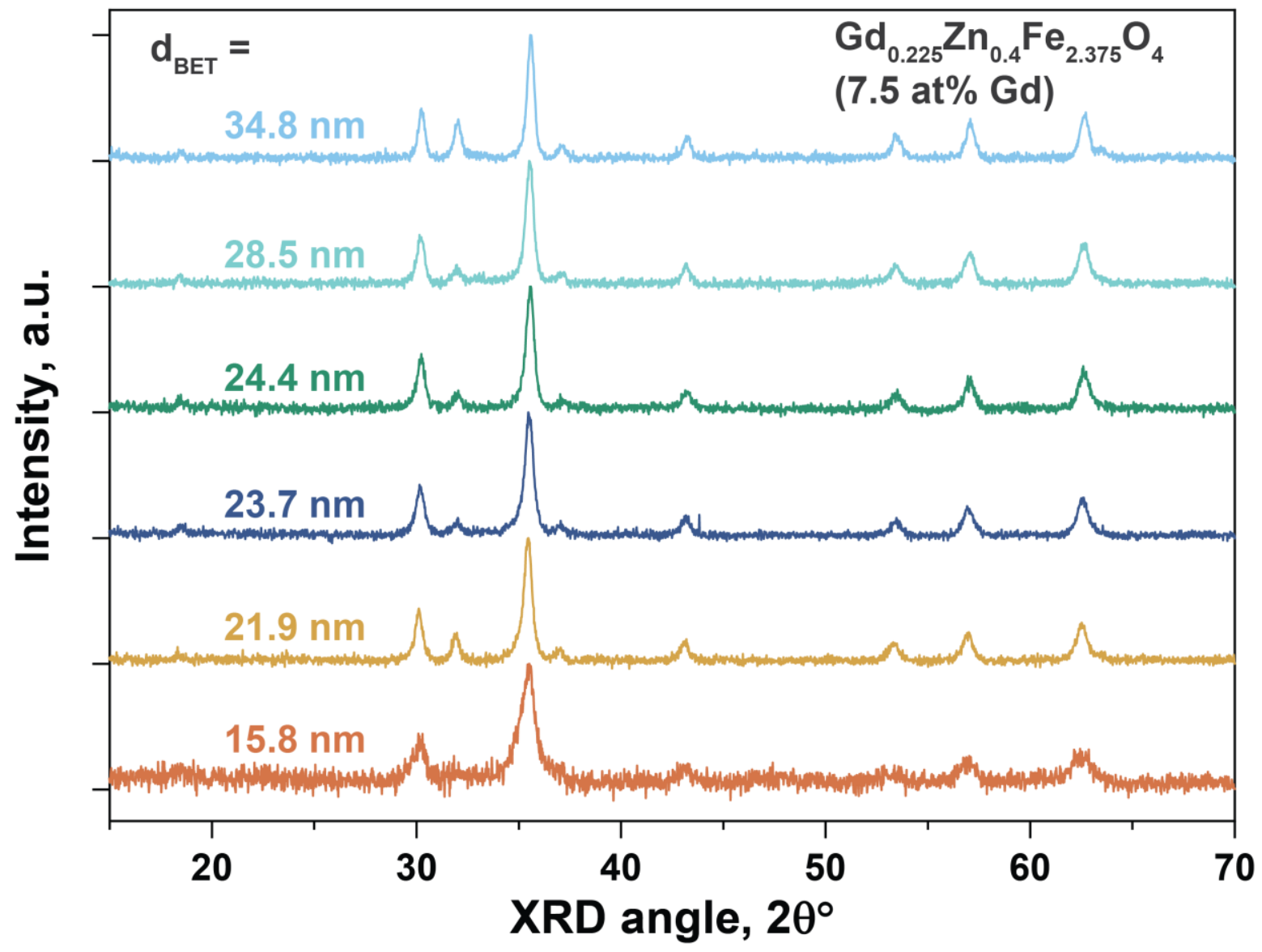

Figure S2: X-ray diffraction patterns of $\mathrm{Gd}_{0.225} \mathrm{Zn}_{0.4} \mathrm{Fe}_{2.375} \mathrm{O}_{4}\left(7.5\right.$ at\% Gd) with varying $\mathrm{d}_{\text {BET }}$. 


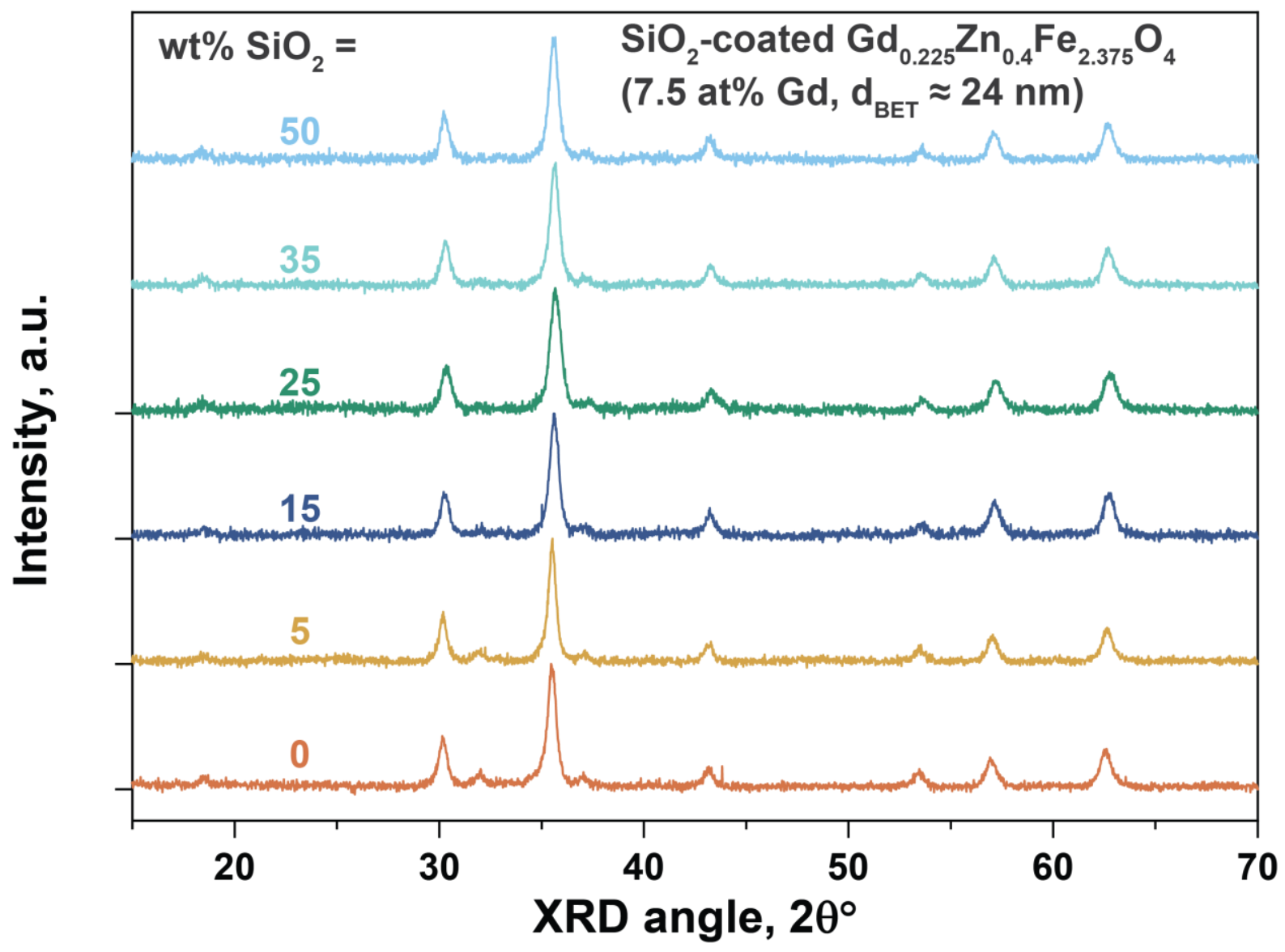

1

Figure S3: X-ray diffraction patterns of $\mathrm{SiO}_{2}$-coated $\mathrm{Gd}_{0.225} \mathrm{Zn}_{0.4} \mathrm{Fe}_{2.375} \mathrm{O}_{4}\left(7.5\right.$ at $\left.\% \mathrm{Gd}, \mathrm{d}_{\mathrm{BET}}=24 \mathrm{~nm}\right)$ with 3 varying $\mathrm{SiO}_{2}$ content $(0-50 \mathrm{wt} \%)$. 


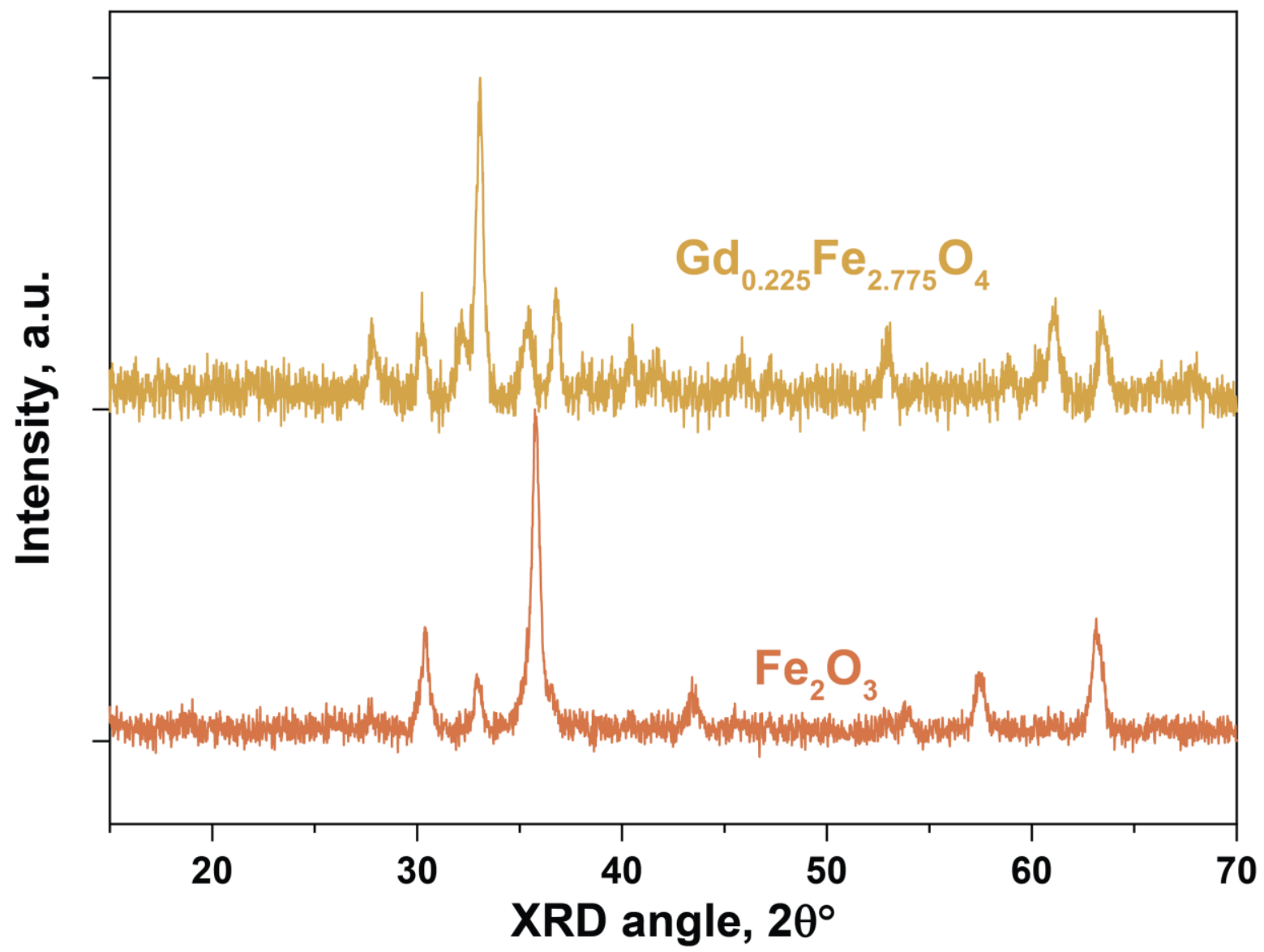

$\frac{1}{2}$

Figure S4: X-ray diffraction patterns of $\mathrm{Gd}_{0.225} \mathrm{Fe}_{2.775} \mathrm{O}_{4}$ and $\mathrm{Fe}_{2} \mathrm{O}_{3}$.

3 


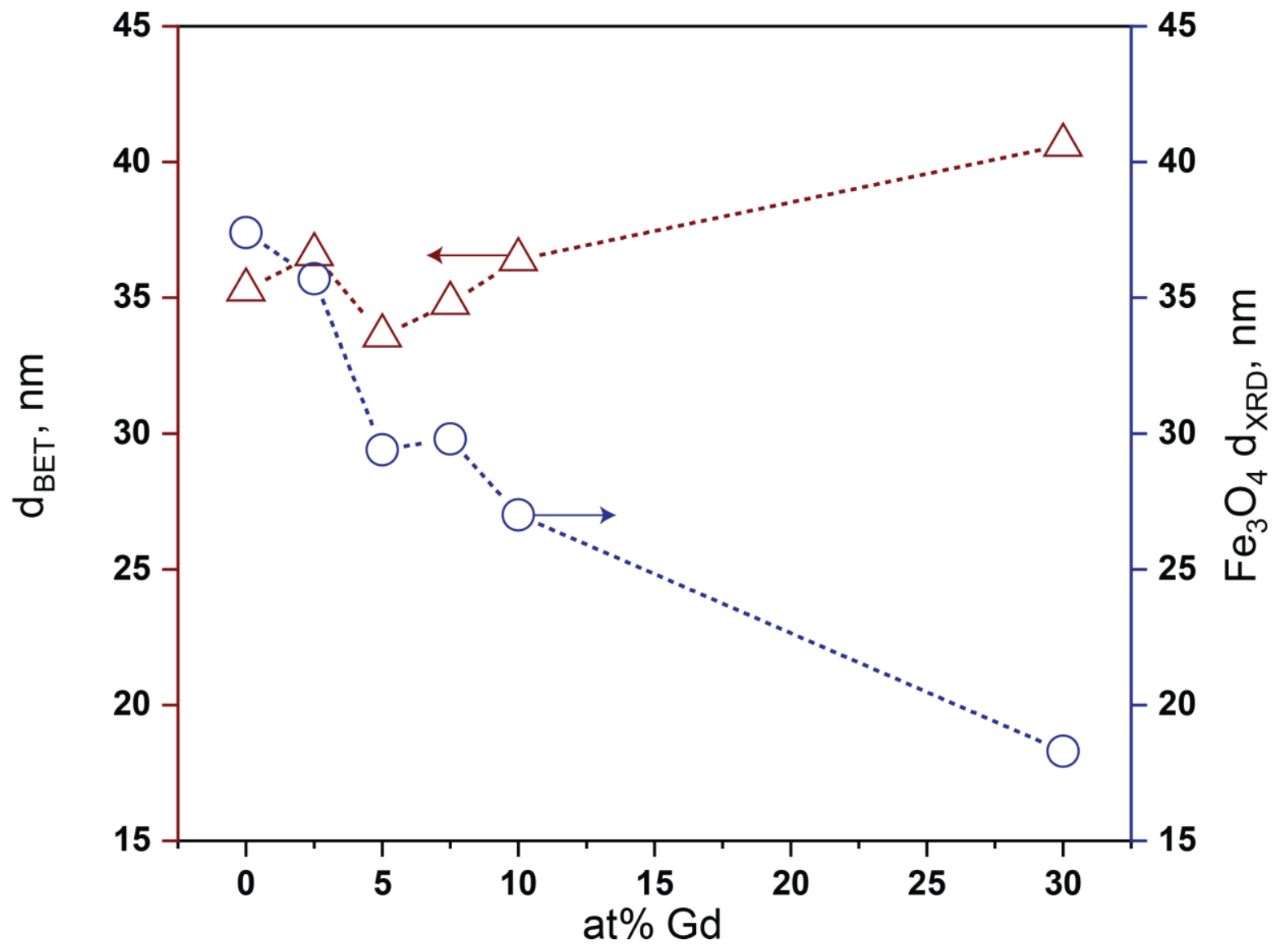

1

Figure S5: Primary particle (red triangles, left axis) and crystal (blue circles, right axis) as a function of 3 at $\% \mathrm{Gd}$.

4

5

6

7

8 

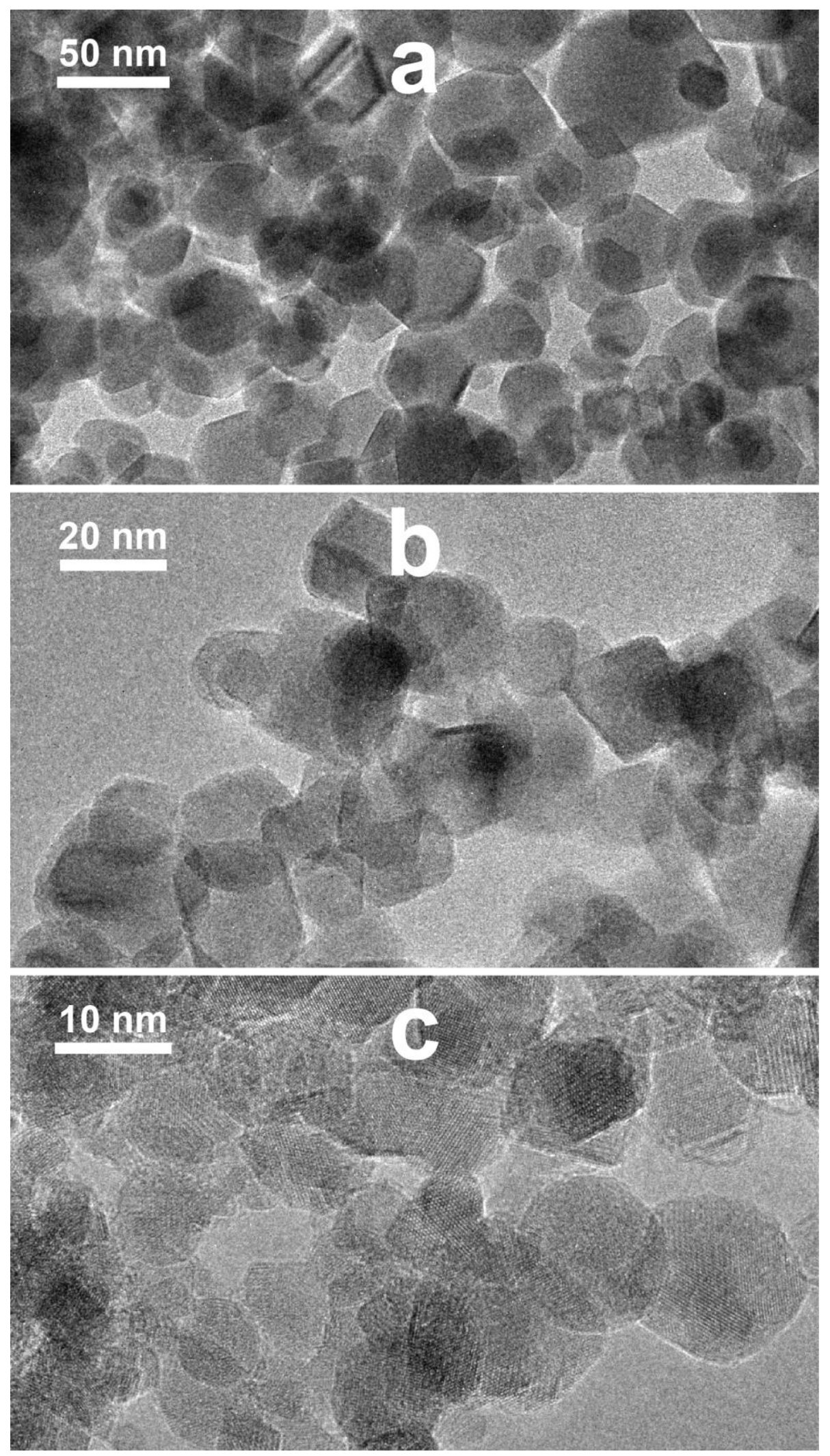

2 Figure S6: Transmission electron images of bare $\mathrm{Gd}_{0.225} \mathrm{Zn}_{0.4} \mathrm{Fe}_{2.375} \mathrm{O}_{4}$ nanoparticles with (a) $\mathrm{d}_{\mathrm{BET}}=15.8 \mathrm{~nm}$ 3 and (b) $23.7 \mathrm{~nm}$, as well as of (c) bare $\mathrm{Zn}_{0.4} \mathrm{Fe}_{2.6} \mathrm{O}_{4}$ nanoparticles with $\mathrm{d}_{\mathrm{BET}}=35.3 \mathrm{~nm}$. 


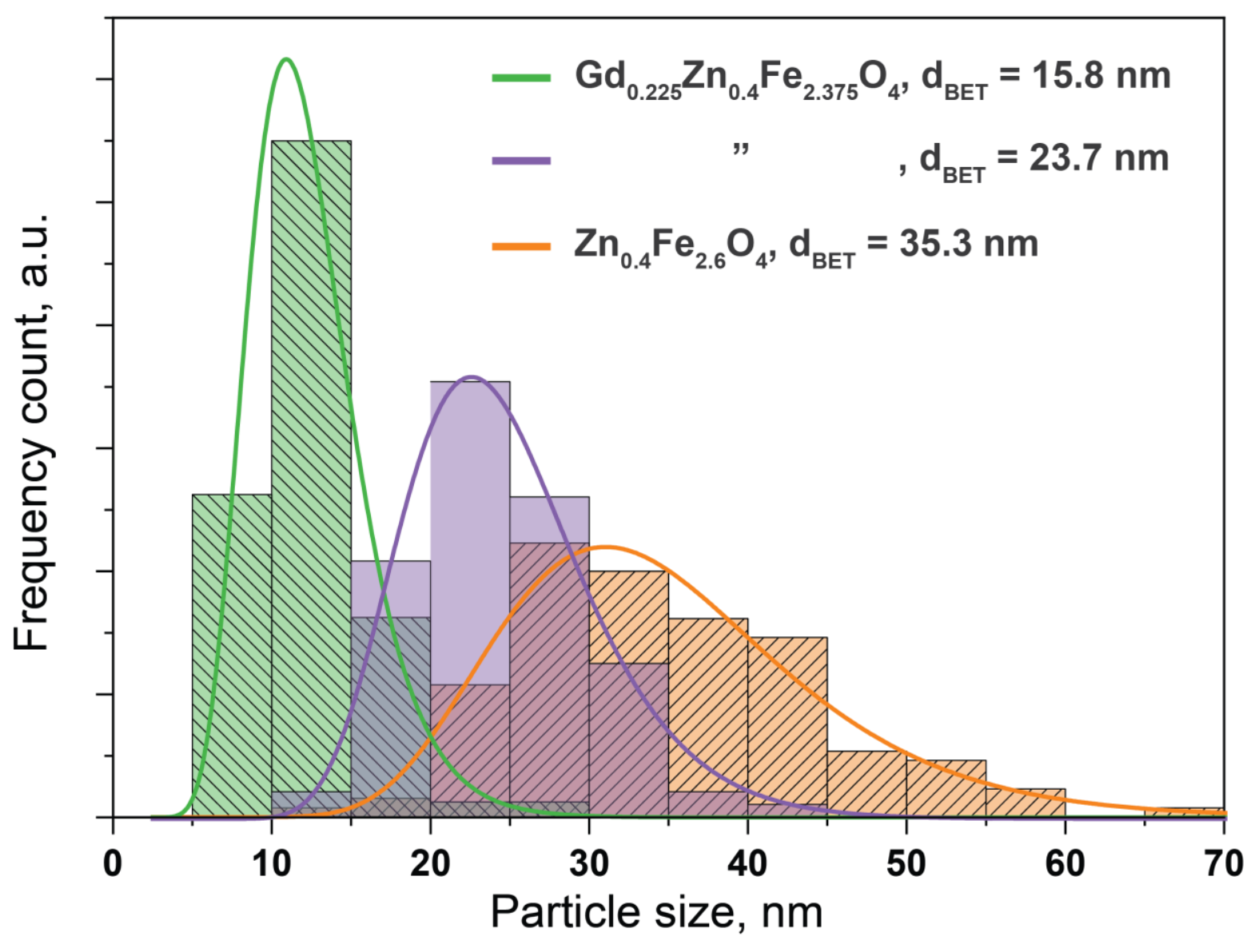

2 Figure S7: Primary particle size distribution of bare $\mathrm{Gd}_{0.225} \mathrm{Zn}_{0.4} \mathrm{Fe}_{2.375} \mathrm{O}_{4}$ nanoparticles with $\mathrm{d}_{\mathrm{BET}}=15.8 \mathrm{~nm}$ 3 and $23.7 \mathrm{~nm}$, as well as of bare $\mathrm{Zn}_{0.4} \mathrm{Fe}_{2.6} \mathrm{O}_{4}$ nanoparticles with $\mathrm{d}_{\mathrm{BET}}=35.3 \mathrm{~nm}$, as determined by image 4 analysis of 80, 96 and 130 particles, respectively. Average primary particle size from TEM (green: $12.6 \mathrm{~nm}$, 5 violet: $24 \mathrm{~nm}$, orange: $35.2 \mathrm{~nm}$ ) correspond well to size from BET. Geometric standard deviations (green: 6 1.32, violet: 1.24 , orange: 1.33 ) indicate a narrow primary particle size-distribution. 


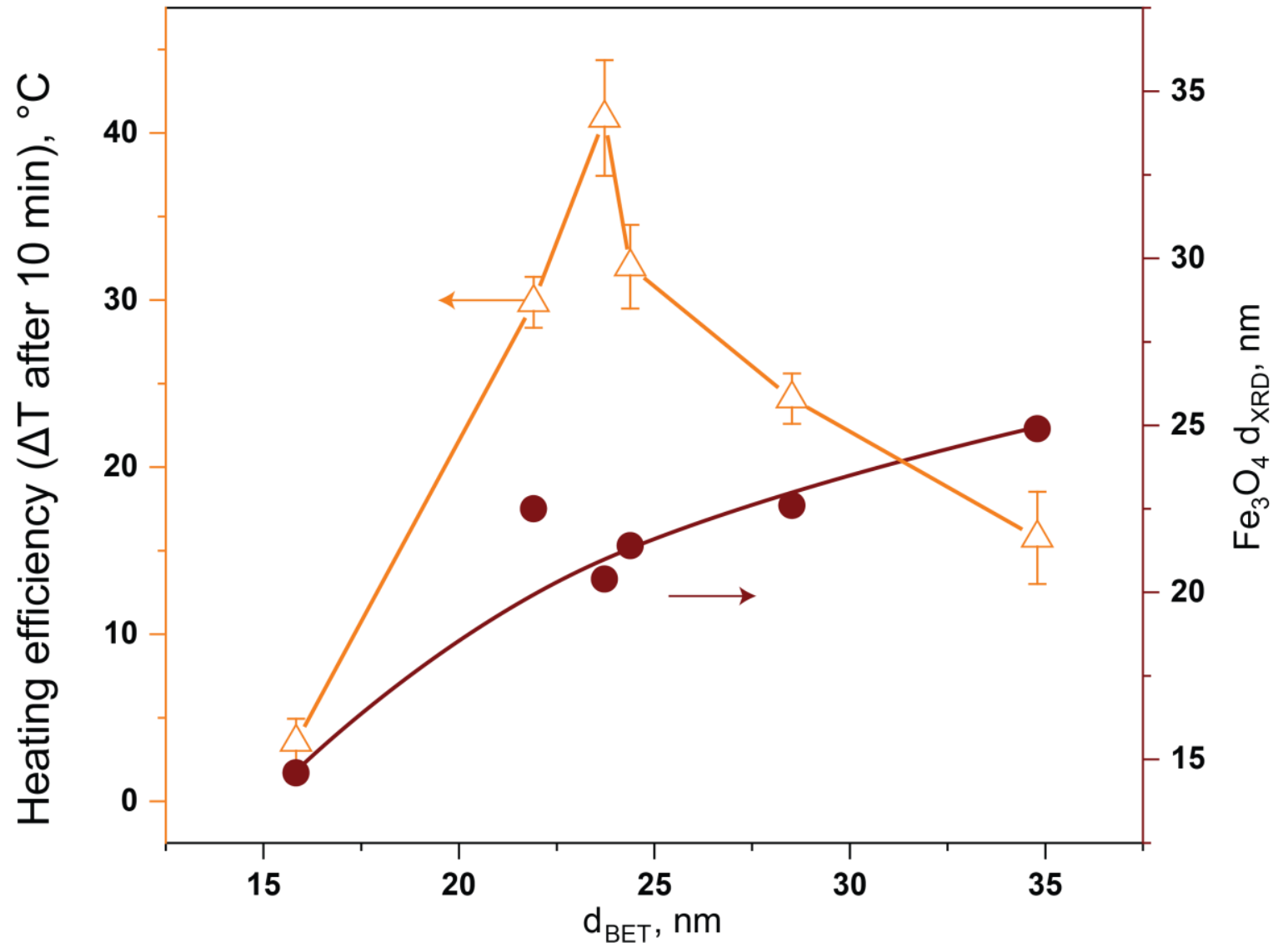

$\frac{1}{2}$

Figure S8: Heating efficiency (triangles) and crystal size (circles) as a function of primary particle diameter,

$3 \mathrm{~d}_{\mathrm{BET}}$, obtained by $\mathrm{N}_{2}$ adsorption.

4 


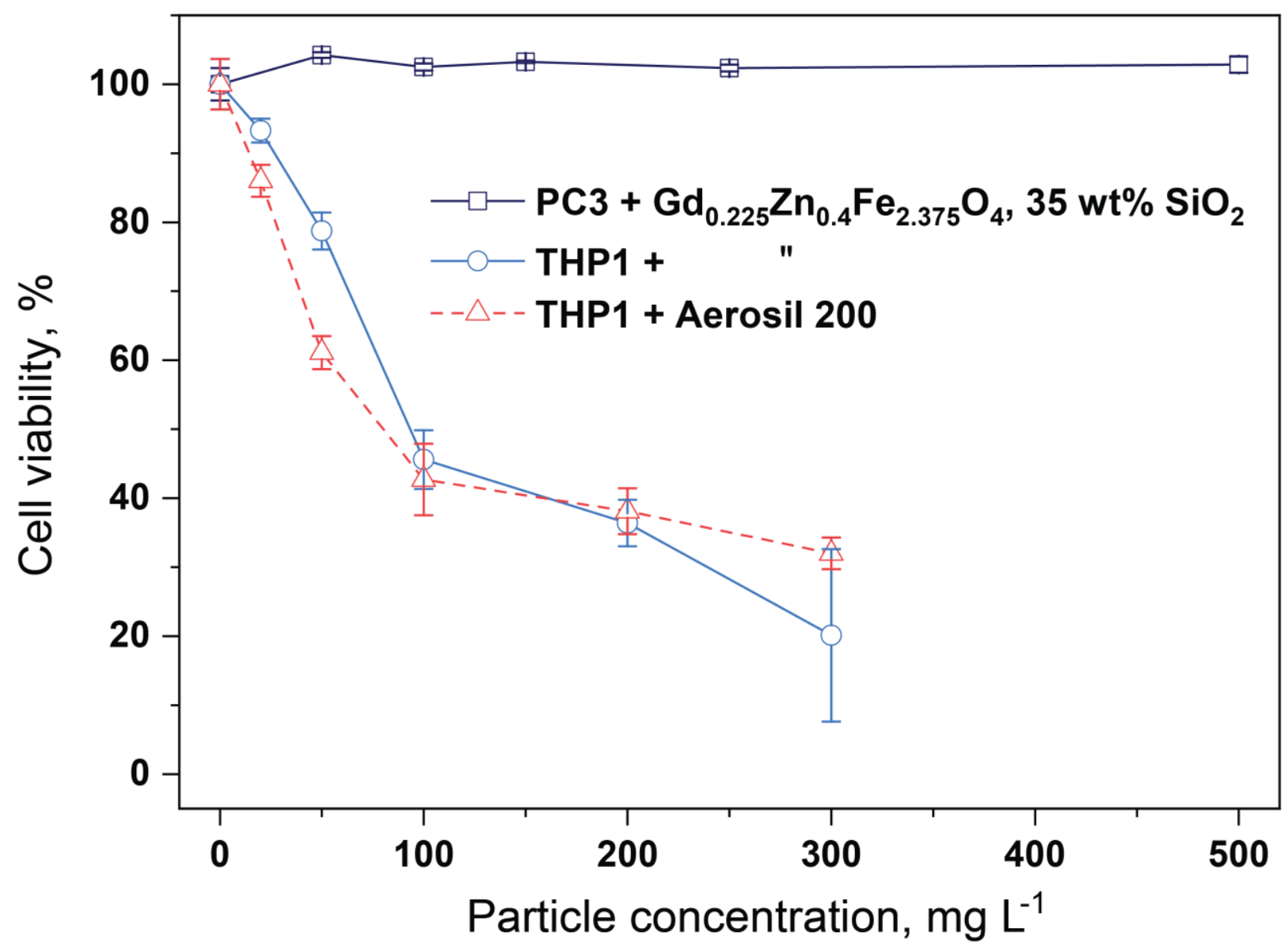

Figure S9: Viability of cancerous cells after incubation for $24 \mathrm{~h}$ with $\mathrm{SiO}_{2}$ coated (35 wt \%)

$3 \mathrm{Gd}_{0.225} \mathrm{Zn}_{0.4} \mathrm{Fe}_{2.375} \mathrm{O}_{4}\left(7.5\right.$ at\% $\mathrm{Gd}$ ) as well as commercial $\mathrm{SiO}_{2}$ (Aerosil 200) nanoparticles at different

4 concentrations. The susceptible THP1 cells show minor toxicity up to $100 \mathrm{mg} \mathrm{L}^{-1}$, very comparable for both

5 investigated nanoparticles. Higher nanoparticle concentrations cause only a small further decrease in

6 viability. Aerosil 200 is considered biocompatible and is frequently used in biological applications. ${ }^{[60]}$ The

7 fact that as-prepared $\mathrm{SiO}_{2}$ coated $\mathrm{Gd}_{0.225} \mathrm{Zn}_{0.4} \mathrm{Fe}_{2.375} \mathrm{O}_{4}$ nanoparticles show comparable biocompatibility

8 suggests that the system can indeed be used for the selective destruction of diseased cells in vivo.

9 Interestingly using PC3 cells instead, the applied nanoparticles do not show any toxicity up to $500 \mathrm{mg} \mathrm{L}^{-1}$. 


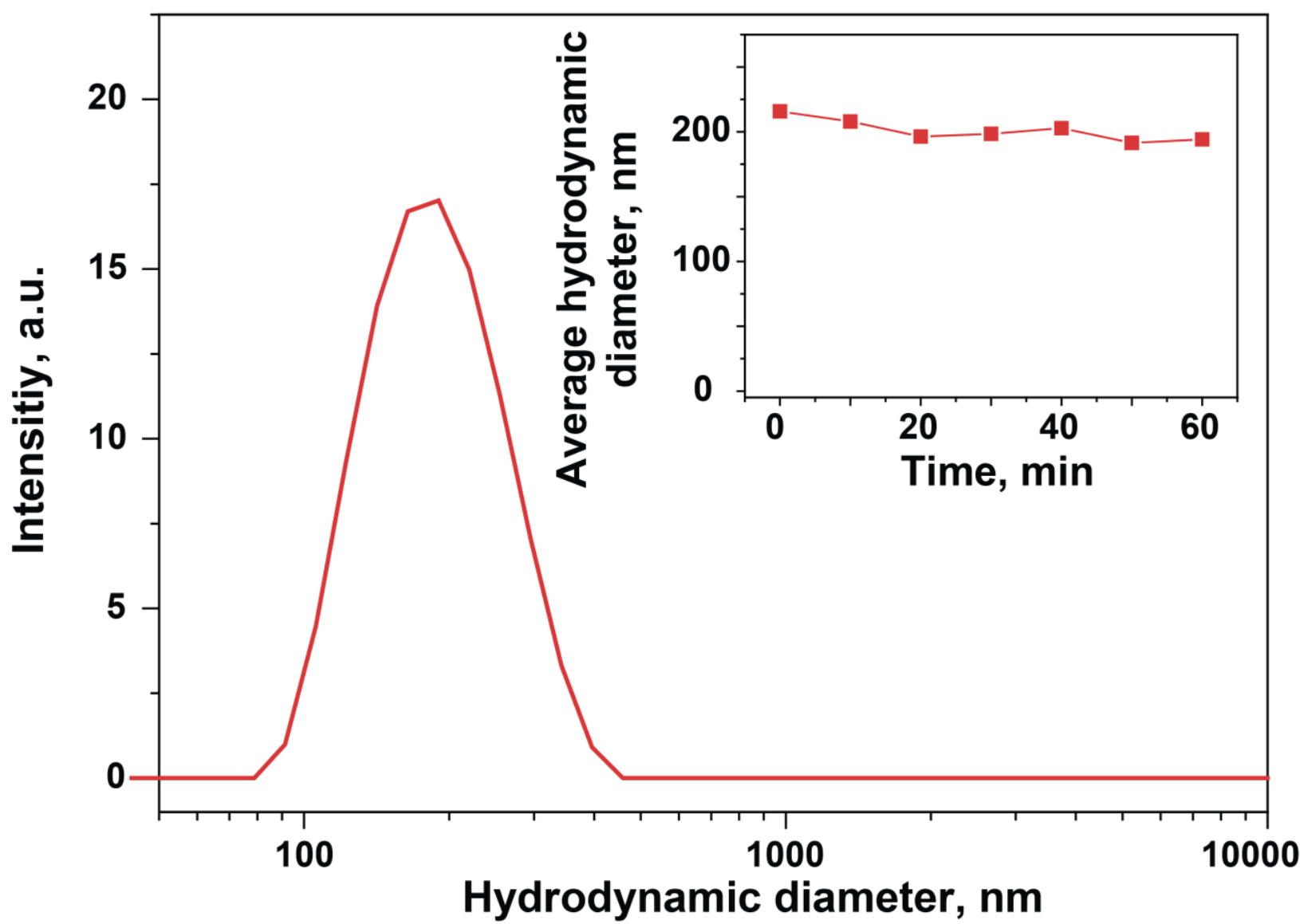

1 Figure S10: Hydrodynamic size distribution of PEGylated $\mathrm{SiO}_{2}$-coated (35 wt $\left.\%\right) \mathrm{Gd}_{0.225} \mathrm{Zn}_{0.4} \mathrm{Fe}_{2.375} \mathrm{O}_{4}$

3 (7.5 at\% Gd) nanoparticles measured by dynamic light scattering. The suspension was prepared at a particle 4 concentration of $0.1 \mathrm{mg} \mathrm{mL}^{-1}$ of $\mathrm{H}_{2} \mathrm{O}$. Inset shows average hydrodynamic diameter over time. 
Table S1: Summary of process parameters and material properties.

\begin{tabular}{|c|c|c|c|c|c|c|c|c|c|c|c|c|}
\hline \multicolumn{4}{|c|}{ Synthesis Parameters } & \multicolumn{3}{|c|}{ Composition } & \multicolumn{6}{|c|}{ Particle Properties } \\
\hline $\mathrm{x}$ & $\mathrm{y}$ & Tube & $\mathrm{C}_{\text {metal }}$ & Formula & $\mathrm{Gd}$ & $\mathrm{SiO}_{2}$ & SSA & $d_{B E T}$ & $d_{X R D}$ & $\begin{array}{c}\Delta \mathrm{T} \text { after } \\
10 \mathrm{~min}\end{array}$ & $\mathrm{M}_{\mathrm{s}}$ & $\mathrm{B}_{\mathrm{CH}}$ \\
\hline $\begin{array}{c}\mathrm{mL} \\
\mathrm{min}^{-1}\end{array}$ & $\begin{array}{c}\mathrm{L} \\
\min ^{-1}\end{array}$ & $\mathrm{~cm}$ & $\mathrm{M}$ & & at $\%$ & wt $\%$ & $\mathrm{~m}^{2} / \mathrm{g}$ & $\mathrm{nm}$ & $\mathrm{nm}$ & ${ }^{\circ} \mathrm{C}$ & $\mathrm{emu} / \mathrm{g}$ & $\mathrm{mT}$ \\
\hline 8 & 3 & 30 & 0.6 & $\mathrm{Zn}_{0.4} \mathrm{Fe}_{2.6} \mathrm{O}_{4}$ & 0 & & 32.89 & 35.3 & 35.1 & 0.83 & 73.42 & 9.48 \\
\hline 8 & 3 & 30 & 0.6 & $\mathrm{Gd}_{0.075} \mathrm{Zn}_{0.4} \mathrm{Fe}_{2.525} \mathrm{O}_{4}$ & 2.5 & & 31.08 & 36.6 & 33.3 & 3.37 & 67.42 & 8.48 \\
\hline 8 & 3 & 30 & 0.6 & $\mathrm{Gd}_{0.15} \mathrm{Zn}_{0.4} \mathrm{Fe}_{2.45} \mathrm{O}_{4}$ & 5 & & 33.22 & 33.6 & 25.5 & 6.97 & 53.06 & 5.99 \\
\hline 8 & 3 & 30 & 0.6 & $\mathrm{Gd}_{0.225} \mathrm{Zn}_{0.4} \mathrm{Fe}_{2.375} \mathrm{O}_{4}$ & 7.5 & & 31.52 & 34.8 & 26.1 & 15.77 & 38.38 & 3.99 \\
\hline 8 & 3 & 30 & 0.6 & $\mathrm{Gd}_{0.3} \mathrm{Zn}_{0.4} \mathrm{Fe}_{2.3} \mathrm{O}_{4}$ & 10 & & 29.62 & 36.4 & 23.4 & 19.1 & 25.72 & 1.99 \\
\hline 8 & 3 & 30 & 0.6 & $\mathrm{Gd}_{0.9} \mathrm{Zn}_{0.4} \mathrm{Fe}_{1.7} \mathrm{O}_{4}$ & 30 & & 23.91 & 40.6 & 18.3 & -0.17 & 1.37 & 1.48 \\
\hline 8 & 3 & 0 & 0.3 & $\mathrm{Gd}_{0.225} \mathrm{Zn}_{0.4} \mathrm{Fe}_{2.375} \mathrm{O}_{4}$ & 7.5 & & 69.26 & 15.8 & 14.6 & 3.53 & 20.11 & 0.98 \\
\hline 5 & 5 & 20 & 0.3 & $\mathrm{Gd}_{0.225} \mathrm{Zn}_{0.4} \mathrm{Fe}_{2.375} \mathrm{O}_{4}$ & 7.5 & & 50.05 & 21.9 & 22.5 & 29.87 & 35.24 & 0.98 \\
\hline 7 & 5 & 20 & 0.3 & $\mathrm{Gd}_{0.225} \mathrm{Zn}_{0.4} \mathrm{Fe}_{2.375} \mathrm{O}_{4}$ & 7.5 & & 44.97 & 24.4 & 21.4 & 32 & 39.49 & 1.99 \\
\hline 8 & 3 & 20 & 0.3 & $\mathrm{Gd}_{0.225} \mathrm{Zn}_{0.4} \mathrm{Fe}_{2.375} \mathrm{O}_{4}$ & 7.5 & & 38.45 & 28.5 & 22.6 & 24.1 & 35.85 & 2.49 \\
\hline 7 & 5 & 20 & 0.3 & $\mathrm{Fe}_{2} \mathrm{O}_{3}$ & 0 & & 46.51 & 25 & 23 & 1.17 & 39.98 & 15.04 \\
\hline 7 & 5 & 20 & 0.3 & $\mathrm{Zn}_{0.4} \mathrm{Fe}_{2.6} \mathrm{O}_{4}$ & 0 & & 45.8 & 25.3 & 25.7 & 9.47 & 68.38 & 5.99 \\
\hline 7 & 5 & 20 & 0.3 & $\mathrm{Gd}_{0.225} \mathrm{Fe}_{2.775} \mathrm{O}_{4}$ & 7.5 & & 40.59 & 27 & 25.2 & -0.67 & 3.88 & 6.49 \\
\hline 7 & 5 & 20 & 0.3 & $\mathrm{Gd}_{0.15} \mathrm{Zn}_{0.4} \mathrm{Fe}_{2.45} \mathrm{O}_{4}$ & 5 & & 44.5 & 25.1 & 20.3 & 22.87 & 49.27 & 2.98 \\
\hline 7 & 5 & 20 & 0.3 & $\mathrm{Gd}_{0.3} \mathrm{Zn}_{0.4} \mathrm{Fe}_{2.3} \mathrm{O}_{4}$ & 10 & & 38.83 & 27.8 & 21.1 & 25.97 & 28.09 & 0.98 \\
\hline 7 & 5 & $20 / 30$ & 0.3 & $\mathrm{Gd}_{0.225} \mathrm{Zn}_{0.4} \mathrm{Fe}_{2.375} \mathrm{O}_{4}$ & 7.5 & 0 & 46.23 & 23.7 & 20.4 & 40.9 & 37.3 & 0.98 \\
\hline 7 & 5 & $20 / 30$ & 0.3 & $\mathrm{Gd}_{0.225} \mathrm{Zn}_{0.4} \mathrm{Fe}_{2.375} \mathrm{O}_{4}$ & 7.5 & 5 & 44.63 & & 23.8 & 13.7 & 45.99 & 2.49 \\
\hline 7 & 5 & $20 / 30$ & 0.3 & $\mathrm{Gd}_{0.225} \mathrm{Zn}_{0.4} \mathrm{Fe}_{2.375} \mathrm{O}_{4}$ & 7.5 & 15 & 54.74 & & 18.3 & 9.6 & 51.51 & 3.49 \\
\hline 7 & 5 & $20 / 30$ & 0.3 & $\mathrm{Gd}_{0.225} \mathrm{Zn}_{0.4} \mathrm{Fe}_{2.375} \mathrm{O}_{4}$ & 7.5 & 25 & 54.09 & & 14.3 & 23.5 & 50.64 & 2.98 \\
\hline 7 & 5 & $20 / 30$ & 0.3 & $\mathrm{Gd}_{0.225} \mathrm{Zn}_{0.4} \mathrm{Fe}_{2.375} \mathrm{O}_{4}$ & 7.5 & 35 & 69.84 & & 18.3 & 42.3 & 53.55 & 2.06 \\
\hline 7 & 5 & $20 / 30$ & 0.3 & $\mathrm{Gd}_{0.225} \mathrm{Zn}_{0.4} \mathrm{Fe}_{2.375} \mathrm{O}_{4}$ & 7.5 & 50 & 97.21 & & 17.5 & 34 & 44.85 & 2.06 \\
\hline
\end{tabular}


